University of Pennsylvania ScholarlyCommons

2014

\title{
Christians in the Amphitheater? The «Christianization» of Spectacle Buildings and Martyrial Memory
}

Kimberly Bowes

University of Pennsylvania, kbowes@sas.upenn.edu

Follow this and additional works at: http://repository.upenn.edu/classics_papers

Part of the Architectural History and Criticism Commons, Christianity Commons, and the Classics Commons

\section{Recommended Citation}

Bowes, K. (2014). Christians in the Amphitheater? The «Christianization» of Spectacle Buildings and Martyrial Memory. Mélanges de l’École Française de Rome: Middle Ages, 126 (1), 93-114. http://dx.doi.org/10.4000/mefrm.1807 


\title{
Christians in the Amphitheater? The «Christianization» of Spectacle Buildings and Martyrial Memory
}

\begin{abstract}
In order to place the site of Sant'Agnese in Agone in its broader late antique and early medieval context, this article presents an overview of the archaeological evidence for Christian spaces inside spectacle buildings stadia, hippodromes, theaters and amphitheaters. It suggests that the «Christianization» of such buildings was very rare, and in only a few cases linked to martyrial commemoration. The paper concludes by suggesting some reasons why spectacle buildings should have been so infrequently associated with martyrial memory.
\end{abstract}

\section{Keywords}

Rome, Salona, Caesarea Maritima, Tarragona, Sant'Agnese in Agone, spectacle buildings, christianization, churches, temples, archaeology, martyrium

\section{Disciplines}

Architectural History and Criticism | Arts and Humanities | Christianity | Classics 


\title{
Christians in the amphitheater?
}

\section{The "Christianization" of spectacle buildings and martyrial memory}

\author{
Kim Bowes*
}

K. Bowes, University of Pennsylvania, kbowes@sas.upenn.edu

\begin{abstract}
In order to place the site of Sant'Agnese in Agone in its broader late antique and early medieval context, this article presents an overview of the archaeological evidence for Christian spaces inside spectacle buildings - stadia, hippodromes, theaters and amphitheaters. It suggests that the "Christianization " of such buildings was very rare, and in only a few cases linked to martyrial commemoration. The paper concludes by suggesting some reasons why spectacle buildings should have been so infrequently associated with martyrial memory.
\end{abstract}

Rome, Salona, Caesarea Maritima, Tarragona, Sant'Agnese in Agone, spectacle buildings, christianization, churches, temples, archaeology, martyrium.

Ever since Gibbon, scholars have been fascinated with the re-use of ancient buildings for Christian ritual. As it was for Gibbon, listening to the footsteps of monks rustling over the same stones that used to form the Capitoline Temple but had become the church of Santa Maria in Aracoeli ${ }^{1}$, the "conversion" of such buildings (the common use of the term is significant) has signified more than a simple change of function, but rather has served as a physical synecdoche for the far more complex, messier process we term the "Christianization" of the ancient world. So evocative was the notion of Christians literally building their churches atop the temples of the traditional religion that previous generations of scholars tended to gloss over the very different archaeological contexts for such conversions - the state and function of the building at time of its conversion, its date, and the frequency with which such substitutions took place. Instead, all such examples were read as marking the deliberate "triumph" of Christianity over paganism, and it was assumed that such triumphalist conversions were the norm ${ }^{2}$.

More recent work has complicated this simple narrative ${ }^{3}$. More careful studies have paid attention to the archaeological succession of temple to church, finding that the temples in question may have been abandoned for centuries and their stones simply quarried for many projects, including churches. In still densely populated cities, temples may have constituted rare available building plots in prime downtown locations. Some temples were wholly erased by the churches atop them, while others were carefully preserved to broadcast the substitution of one building for the other. Finally, it now seems clear that in most regions of the empire, the vast majority of temples were simply left to decay and nothing was built over or with

* Thanks to Claire Sotinel for inviting me to participate in this conference, and to Rivka Gersht, Ken Holum, Richard Hodges, Bob Ousterhout, Luke Lavan, and Rubina Raja for valuable bibliographic help.

1. Gibbon 1984, p. 16.

2. The seminal article was Deichmann 1939, whose general conclusions were followed by many: Fowden 1978; Trombley 1993; Saradi 1990; Saradi 2006.

3. Hanson 1978; Ward-Perkins 2003; Bayliss 2004; and the articles collected in Lavan - Mulryan 2011, esp. Lavan 2011. 
their remains - either a kind of death by snubbing, or simply a disinterest in the kind of pagan-Christian fisticuffs with which modern scholars have been so fascinated.

Those interested in the material culture of "Christianization" have largely focused on temple-church conversions. The use of spectacle buildings for churches has seen less systematic study, but has been assumed to be both ubiquitous and thus pregnant with triumphalist meaning ${ }^{4}$. Amphitheaters, hippodromes, stadia, and theaters - what I shall here shorthand as «spectacle buildings " - are assumed to have been the spaces of Christian martyrdom. Thus, the appearance of later churches in these spaces is often thus interpreted as marking the actual locus where the martyr met his or her death, and thus the elevation of the criminals of one regime to the heroes of another.

This brief essay suggests that the construction of Christian churches in spectacle buildings demonstrates much of the same ambiguity as those built into temples, and rarely conforms with the expectations of modern scholarship. In brief, I will suggest that the re-use of spectacle buildings for Christian functions is far rarer than is typically supposed: the great majority of amphitheaters, theaters, hippodromes and stadia did NOT see Christian buildings constructed in their remains. Sant'Agnese in Agone is thus an exception, both in Rome and empire-wide. Second, I will suggest that we cannot assume that all, or even the majority of these churches are martyria. Rather, churches in spectacle buildings had a variety of functions - to banish the cultic aspects of traditional spectacle or to complement them, to serve as private funerary chapels or as communal neighborhood churches. That spectacle buildings should have so inconsistently connected with martyrs' deaths points up an important and unexpected disconnect in the late antique imagination between the act of martyrdom, and the place of its happening.

4. E.g. Saradi 2006, p. 301, 322; Vaes 1989, p. 306 ; c.f. Cantino Wataghin 1999, p. 723-4, who is far more cautious.
THE CHRISTIAN RE-USE OF SPECTACLE BUILDINGS : AN ARCHAEOLOGICAL OVERVIEW

The many and diverse uses of ancient buildings in the late antique city has been amply catalogued, and ranges from continued use for their original purpose, simple abandonment, quarrying for building stone, sub-division for private habitation or industrial functions, re-use for burials, and of course, conversion to Christian use ${ }^{5}$. The fate of spectacle buildings, on the other hand, has been particularly poorly documented. $19^{\text {th }} \mathrm{C}$. excavators found them irresistible and, keen to expose the Greek or Roman fabric, ripped through the later levels typically without any accompanying documentation ${ }^{6}$. The losses inflicted through this treatment were not limited to late antique remains, but in many cases included nearly a millennia of active re-use ${ }^{7}$. However, even from the poor evidence left to us, it seems plain that spectacle buildings underwent most of the same range of late antique and early medieval transformations as did the rest of the city: for example the stadium of Aphrodisias was converted into an amphitheater in the late $4^{\text {th }} /$ early $5^{\text {th }} \mathrm{c}$. and continued to be used as such for at least a century; the theater at Málaga was built over by fish-sauce factories and houses in the $4^{\text {th }}$ c.; while the amphitheater at El Jem was reused as a part of the urban fortification by the $6^{\text {th }} c^{8}$.

Relatively few spectacles buildings preserve evidence of late antique Christian use. I have assembled about twenty such examples. This number is almost certainly too low to be a perfect representation: the attrition caused by early excavations must have accounted for some, and my own research may have missed one or two documented examples. Nonetheless, among the hundreds of Greco-Roman amphitheaters, thea-

5. The bibliography is now vast and can be best approached through a series of collected essay volumes: Brogiolo Ward-Perkins 1999; Brogiolo - Christie - Gauthier 2000; Lavan 2001; Krause - Witschel 2006.

6. For example, no mention is made of any post-Roman additions to the Theater of Dionysius in Athens in the early reports, despite the presence of a small funerary church, graves and later cisterns: Pickard-Cambridge 1946; Dörpfeld - Reisch 1896.

7. On the long-term use of the Arles and Nîmes amphitheaters, see Pinon 1979. See also Bowes 2006.

8. See respectively, Roueché 1991, p. 99-108; Rodriguez Oliva 1993, p.183-194; Bomgardner 2000, p. 150. 


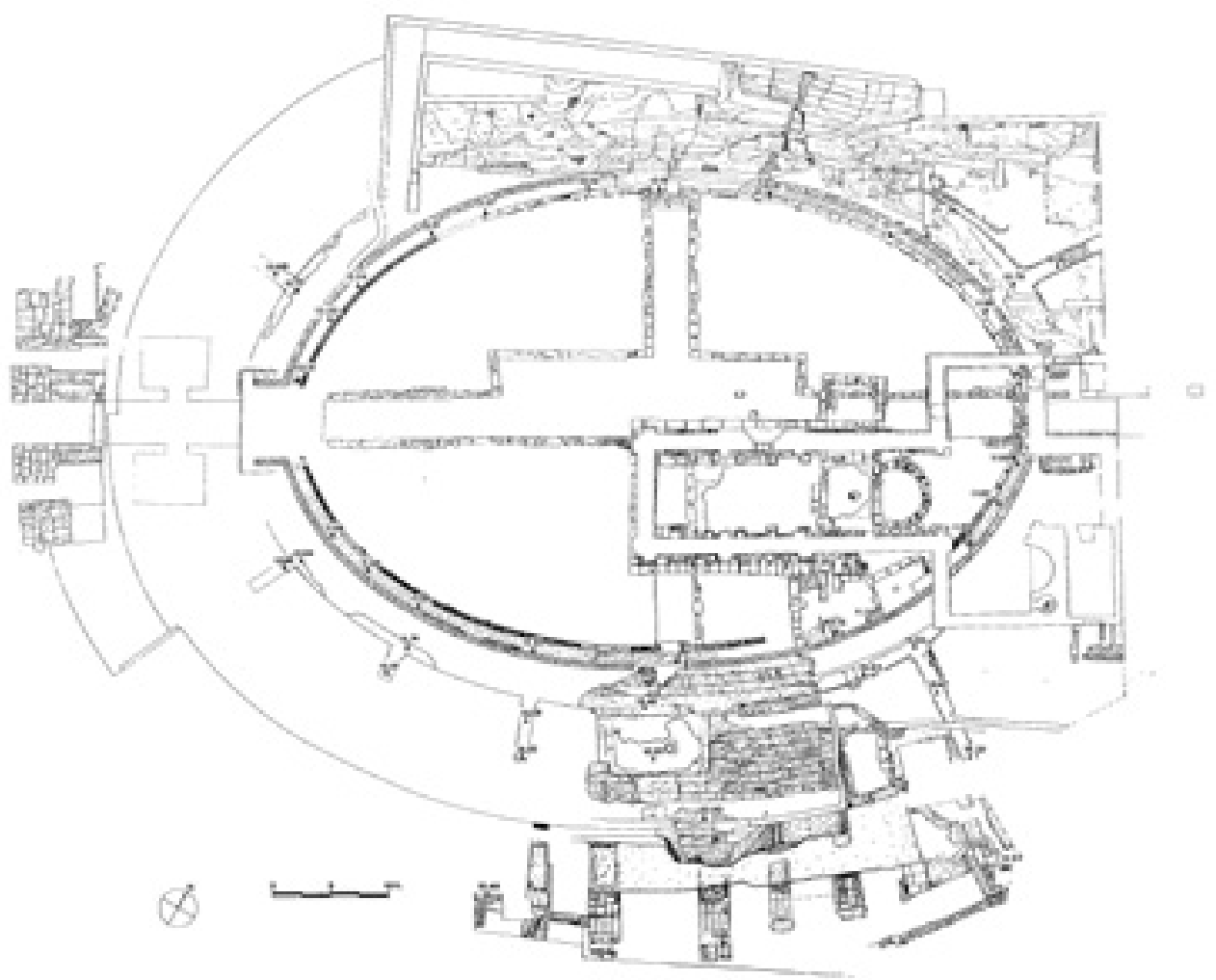

Fig. 1 - Plan, amphitheater and church, Tarragona: later Romanesque church is shown in outlines (C. Godoy Fernández, Basilica de l'amfiteatre de Tarragona, in Del Romà al Romànic, Barcelona, 1999, p. 178).

ters, hippodromes and stadia that were visible during late antiquity and the early Middle Ages, even the lacunose data suggests that re-use as Christian space was neither typical nor frequent. Furthermore, only a handful of these examples can be shown to be martyrial commemorations. While it is often assumed, both by the excavators and by scholarship more generally, that churches constructed inside or near spectacle buildings were necessarily martyria, built in late antiquity to commemorate a local martyr who met his or her death in these buildings, the archaeological evidence is rarely so conclusive. Only about three convincing examples have been found, while the function of the majority of others is either unclear or clearly not martyrial.

A late $5^{\text {th }}$ to early $6^{\text {th }} \mathrm{c}$. church in the arena of the amphitheater at Tarragona, Spain, is perhaps the best-documented martyr church in a spectacle building, its situation now even clearer thanks to new excavations ${ }^{9}$ (fig. 1). The church was deliberately placed over the arena, where, according to their early acta, the martyrs Fructuosus, Auguerius and Eulogius were burned to death ${ }^{10}$. The single aisled church with horseshoe-shaped apse and adjacent burial annex included a lateral stair leading down to the amphitheater's substructures, or fossae, which formed a kind of crypt and seemingly commemorated as the actual point of martyrdom. This spot and the church generally attracted dozens of contemporary ad sanctus burials.

A second reasonably, although not wholly convincing example is another amphitheater church, this in the substructures beneath the amphitheater in Salona ${ }^{11}$ (figs. 2 and 3). The excavator identified two spaces beneath the podium

9. The new excavations are summarized in Godoy 1999, p. 177-179.

10. AASS Jan. II, col. 340 .

11. Dyggve 1933, p. 108-110, 141-146 (dating). 


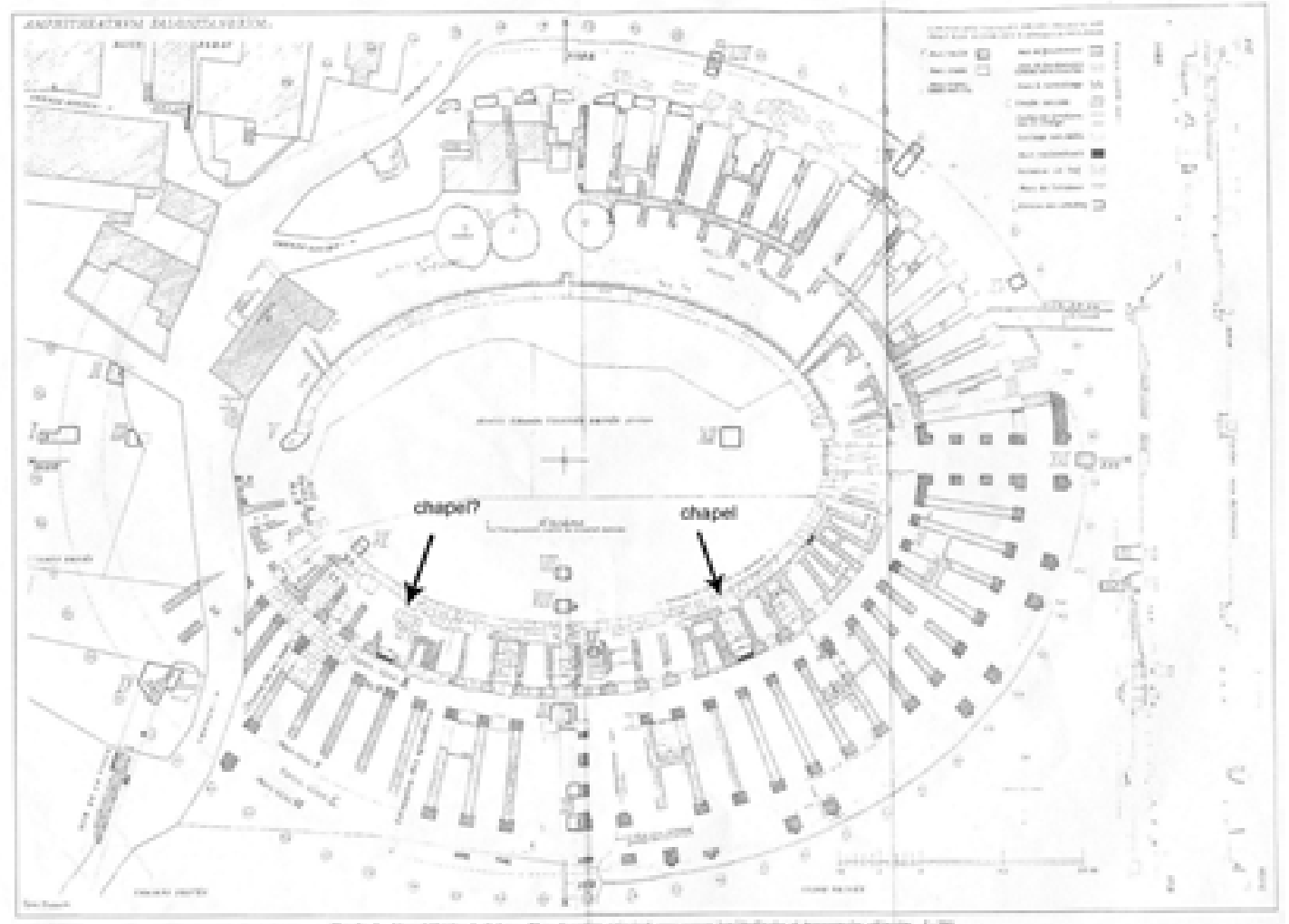

Fig. 2 - Plan, amphitheater, Salona, indicating location of chapels (after E. Dyggve, Recherches à Salone, Copenhagen, 1933, vol. 2, pl. 1).

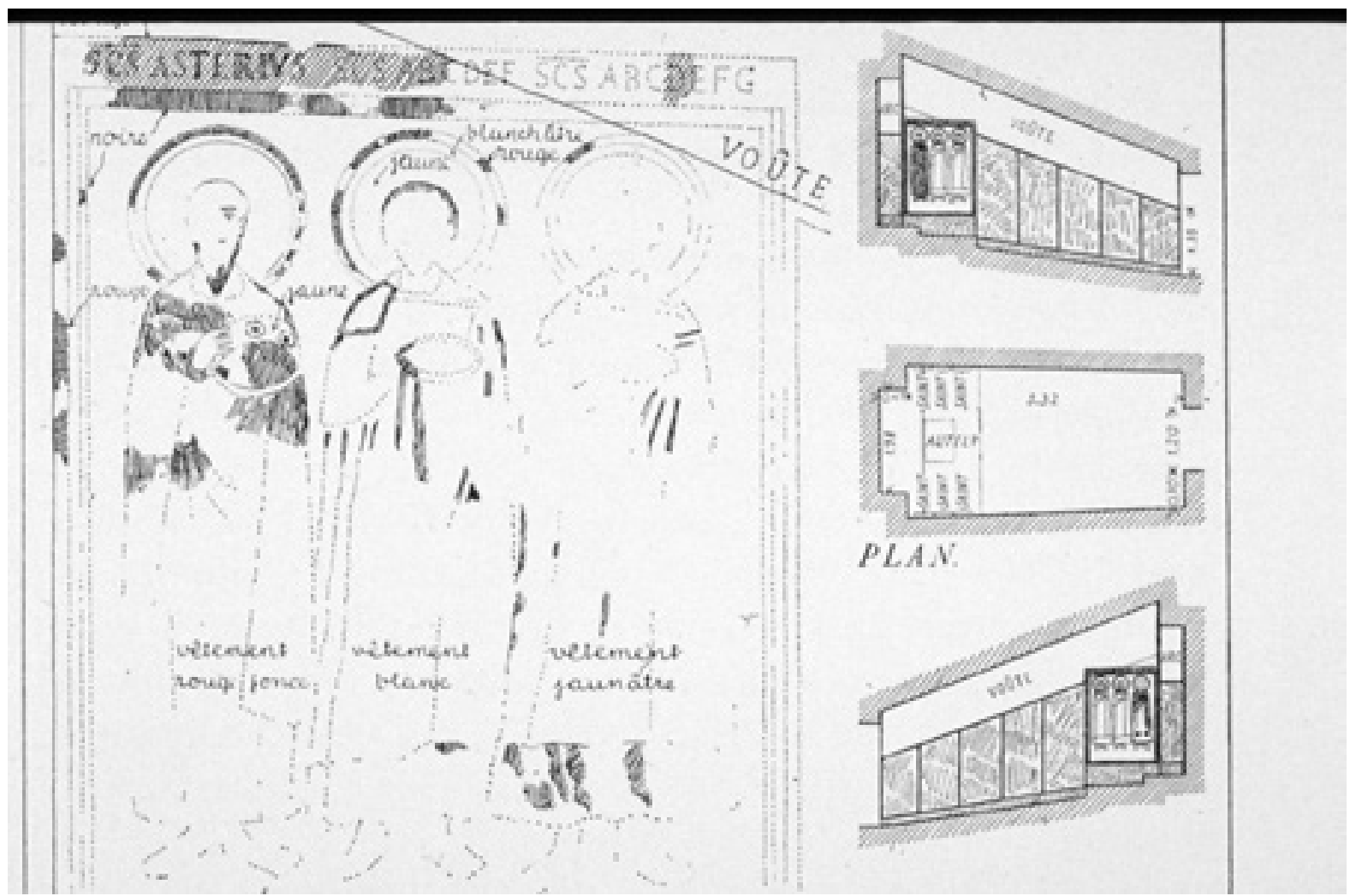

Fig. 3 - Plans, sections and drawing of frescos, chapel in the amphitheater, Salona (E. Dyggve, Recherches à Salone, Copenhagen, 1933, vol. 2, fig. 56). 


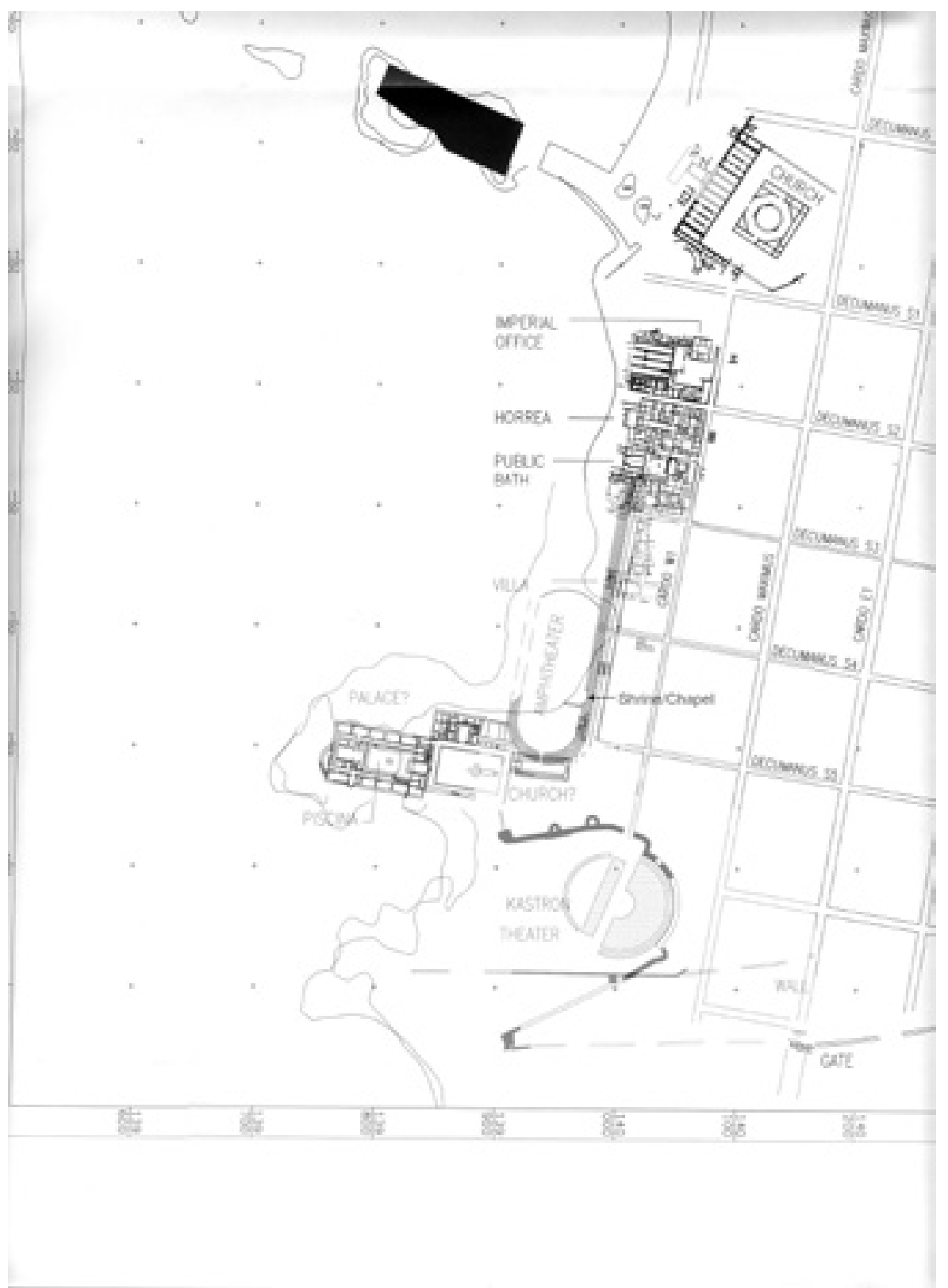

Fig. 4 - City plan, Caesarea southern section in the $4^{\text {th }}-6^{\text {th }}$ C., showing location of Herodian 'hippo-stadium' turned amphitheater, shrine/ chapel and church to the south (after A. Raban and K. Holum (eds.), Caesarea Maritima. A Retrospective after Two Millennia, Leiden, 1996 , overall site plans).

and directly accessible from the arena as shrines to Nemesis, although without any conclusive evidence for their religious use. Both of these spaces were later blocked off from the adjacent corridor, and the eastern of these spaces was later covered with frescoed images of standing, nimbate saints, one of whom is inscribed "Asterius". Asterius was a Salonitan martyr who was allegedly martyred under Diocletian, and made famous by Pope John IV who translated his body along with his fellows to the pope's new chapel off the Lateran Baptistery in Rome. The amphitheater chapel was thus been interpreted as a martyr shrine to Asterius and other Salonitan martyrs, and dated to the mid- $6^{\text {th }}$ c. on the basis of similarities between its walls and that of the city's new fortifications, fortifications which are assumed to have marked the cessation of the use of the amphitheater for spectacles. It should be noted that there is virtually no early information on the Salonitan martyrs besides 


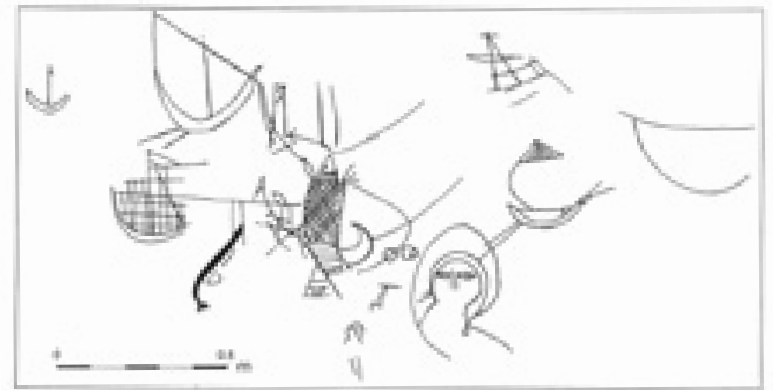

Fig. 5 - Drawing of graffiti from Christian chapel in the amphitheater, Caesarea (Y. Porath, The Caesarea excavation project, in Hadashot Arkheologiyot. Excavations and Surveys in Israel, 17, 1998, fig. 7).

their inclusion in the Martyrologium Hieronymianum and the images in John's Lateran oratory, while their passio is medieval in date ${ }^{12}$. In none of these sources is an amphitheater or any other building named as the place of martyrdom.

The final and most archaeologically rich candidate for an amphitheater martyr's church is in Caesarea Maritima (figs. 4 and 5). Here the multi-functional "hippo-stadium " built by Herod the Great had, by the early $2^{\text {nd }} \mathrm{c}$. or later, shrunk into an oval amphitheater ${ }^{13}$. In the cavea beneath what may have become the amphitheater's pulvinar, or main viewing box ${ }^{14}$, on the eastern side, was built a small shrine with three small rooms each with niches cut into the living rock. Sculptural finds including votive feet dedicated to Kore and perhaps Isis, and images of Hecate and Serapis as Hades, all suggest a shrine to chthonic deities, comparable to the shrines of Nemesis that are found in the cavea of western amphitheaters ${ }^{15}$. Even after the amphitheater was abandoned for spectacle use, either in the $3^{\text {rd }} \mathrm{c}$. or later, and a sizeable residential neighborhood began to encroach over the arena, the shrine seems to have been used and even expanded. At some point in the $4^{\text {th }}$ - c., a small building was built over the seats and arena: thus far, no plan of the building has been produced, but descriptions suggest it was positioned directly over the earlier shrine. The building preserved remains

12. See AASS April II, col. 5-8.

13. For the excavations, see Porath 1995; Porath 1996. The Christian evidence is most expansively discussed in Porath 1998, p. 41-44. The dating of the conversion into amphitheater is contested: see Patrich 2002, p. 345.

14. See the suggestion by Humphrey 1996, p. 128.

15. On the sculpture, see Gersht 1996. of painted plaster, some of which was both incised and painted and included images of a nimbate figure, boats and fish. The earlier niches contained $4^{\text {th }}-6^{\text {th }}$ c. lamps, suggesting the continued use of these spaces. The excavators interpret this as a Christian chapel that replaced the earlier chthonic shrine. Also during at some point during the $4^{\text {th }}$ $6^{\text {th }}$ c., the southern curve of the amphitheater was covered with a large Christian basilica, although its date is uncertain.

The relationship between the Caesarean amphitheater shrine and nearby basilica is not clear from the preliminary reports. The chapel could represent a conversion of the previous pagan shrine, and the church a neighborhood church that served the immediate population. That one or both might be something more is mostly suggested by Caesarea's particularly vibrant local martyrial tradition, a tradition due almost entirely to the efforts of Eusebius of Caesarea, who himself survived a local persecution and worked to promote the veneration of local martyrs. Eusebius claims that several of the city's martyrs died as part of spectacular performance - Timotheus, Theophilus and Theotimus who were condemned to fight in a gladiatorial contest, Auxentius, Adrianus and Eubulus who were condemned ad bestias, and Agapius and Silvanus who were tortured in the $\sigma \tau \alpha \delta i \omega$ or stadium $^{16}$. J. Patrich has suggested that as the city's most venerable place of spectacle, the stadium described by Eusebius, [delete comma] is most likely Herod's hippo-stadium-turned amphitheater, and that the Christian chapel was thus built to commemorate Agapius and/or Silvanus ${ }^{17}$. Again, the most recent archaeological reports make it impossible to be certain of the presence of martyr cult, let alone who those martyrs might be, but the hypothesis is an attractive one, not least because of the city's early martyrological tradition.

After Tarragona, Salona and Caesarea, the evidence becomes far murkier. At Thessaloniki, similarly provocative textual connections between church and local martyrologies turn out to be far
16. See Eusebius, Martyrs of Palestine (Bardy 1967) 7.4, 8.2-3; $7.4,11.30 ; 3.2$ and 6.3 , respectively. On Silvanus, Syriac version of the Martyrs of Palestine, 51 (Cureton 1861).

17. Patrich 2002. 


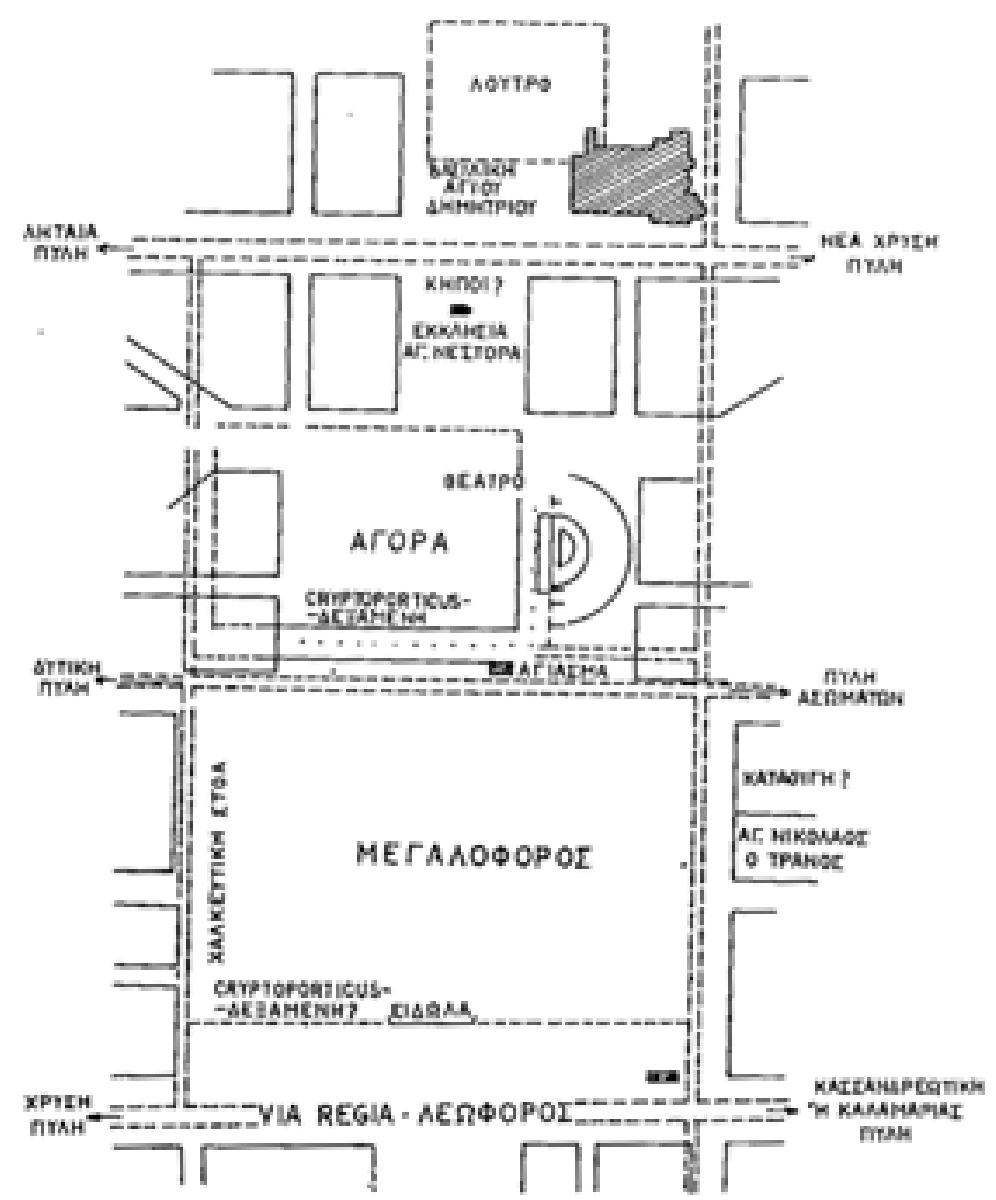

Fig. 6 - Plan of agora, Thessaloniki (after C. Bakirtzis, 'H Á international d'archéologie chrétienne, Thessalonique, 1980, Rome, 1984, vol. 2, fig. 1).

more tenuous on the ground. The fragmentary remains of a church, possibly of late antique date, were found built over what appears to be a stadium next to the agora ${ }^{18}$ (fig. 6). Local tradition identified the church as being dedicated to St. Nestor. One of the $9^{\text {th }}$ c. martyrologies of Saint Demetrios claims that the Christian Nestor challenged and killed the emperor Galerius' favorite gladiator in a stadium, a deed which. according one set of $9^{\text {th }} \mathrm{c}$. passiones, ultimately led to the death of both Nestor and Demetrios in that stadium ${ }^{19}$. IF this church were originally dedicated to Nestor, and IF the $9^{\text {th }}$ c. passio was based on a late antique tradition, this church might be a locus sanctus built over the place of martyrdom. The many uncertainties, however, not to mention the lacunose state of the archaeology, leave more questions than answers.

So persistently is the spectacle building associated with martyrdom in the modern imagination that has proven easy to overlook the many other functions that associated Christian buildings might have. For instance, not far from the above-men-

18. Bakirtzis 1984, p. 7-9.

19. The martyrial traditions are late, complex and much debated. Three versions of a shorter passio (BHG 496; BHL 2122; Photius, Bibliotheca, 255) and one version of a longer passio survive (BHG 497), none of which can be shown to be prior to the $9^{\text {th }} \mathrm{c}$. There is also a $10^{\text {th }} \mathrm{C}$. version by Simeon Metaphrastes (BHG 498). The shorter, and some say earlier, passiones do not mention the death of Nestor

only Demetrios, at the stadium. Another tradition has Nestor being slain outside the Golden Gate of the city. For two different views of the passiones' historical veracity and an overview of the problems, see, Skedros 1999; Woods 2000 . 


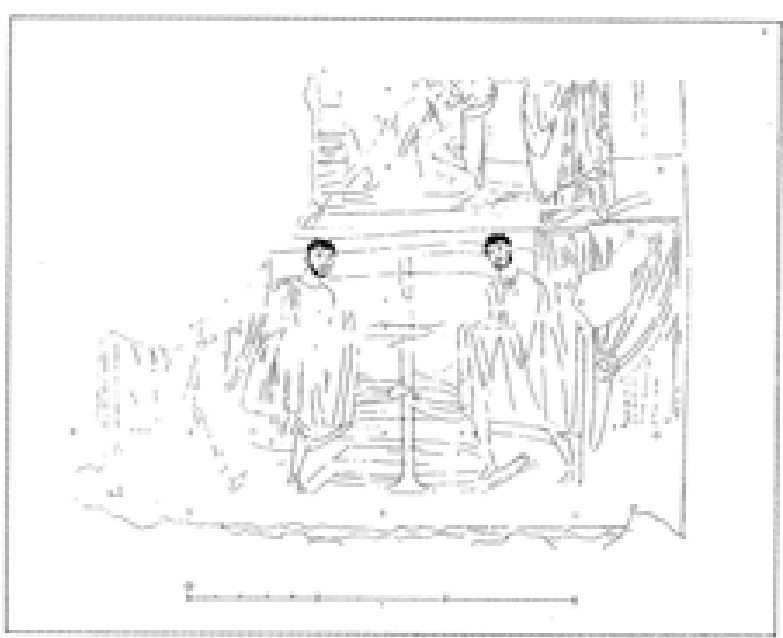

Fig. 7 - Drawing of fresco from cryptoporticus of the theater/

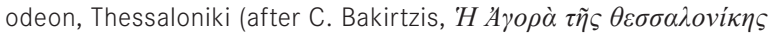
$\sigma \tau \alpha \grave{~} \pi \alpha \lambda \alpha \imath o \chi \rho \imath \sigma \tau \iota \alpha v \imath \kappa \grave{\alpha} \chi \rho o ́ v \imath \alpha$, in Acts du Xe Congress international d'archéologie chrétienne, Thessalonique, 1980, Rome, 1984, vol. 2, fig. 3).

tioned church of St. Nestor in Thessaloniki, a cryptoporticus surrounding the theater-odeon complex was partially converted to use as cisterns during the later $6^{\text {th }} \mathrm{c}$. (see fig. 6 ). The water-outlet room of these cisterns was decorated with frescos depicting two youthful bearded men with covered hands worshiping a large cross, with other more fragmentary figures above (fig. 7).

The bearded men have been identified as Kosmos and Damian, and the fragmentarily preserved figures above a group of Thessaloniki's martyrs, such as Demetrios and Nestor ${ }^{20}$. Whoever these figures are, their presence is most likely called upon here to protect and bless the water supply - a common component of a late antique city's apotropaic apparatus ${ }^{21}$. Even were they Thessalonikian martyrs, their presence in this pipe room would be directed principally towards this protective end rather than to mark a locus sanctus.

The reuse of spectacle buildings for human habitation might require a concomitant « neighborhood" church that might also be built amid or near the building's ruins. The church at the hippodrome complex at Gerasa is set some $10 \mathrm{~m}$ to the east of the hippodrome's south end and ignores its orientation entirely (fig. 8).

20. Bakirtzis 1984, n. 18, p. 13-18.

21. Sauer 2011; Thür 1996.
Instead, the church follows that of the adjacent road and earlier buildings along side $\mathrm{it}^{22}$. Some of those buildings may have been funerary in nature, for the church is sandwiched between two cave tombs of Roman date, re-used for Christian burials. A small single-aisled affair culminating in a small sanctuary complete with altar, reliquary and synthronon, the church is paved in fine geometric mosaics, which include a dedication inscription mentioning the bishop Marianos, and a donor inscription ascribing the work to five people, seemingly laymen. Later additions include a narthex and a small chamber to the north side, identified as a diakonikon. Across the street, the adjacent cavea of the hippodrome were also reused at the same time the church was constructed, and received similar, albeit somewhat less fine mosaic floors. These include two inscriptions mentioning donations, and a third that names a deacon Elias. While termed the "house of Elias" in the reports, there is nothing in the archaeology that suggests domestic use and the donative inscriptions on the contrary suggest functions associated with the church - perhaps a place for the collection of charitable donations, a kind of deaconia. Indeed, in the later $6^{\text {th }} \mathrm{c}$. when church was built, the northern half of the hippodrome may still have been in use: the presence of substructures along the building's axis and a semi-circular enclosure wall forming a truncated oval surely point to this portion being closed off and used as an amphitheater - a relatively common occurrence in Asia Minor and Palestine ${ }^{23}$. This must have taken place at some point in the later $3^{\text {rd }}$ or $4^{\text {th }}$ c. A mosaic inscription mentioning the Blue racing faction found elsewhere in the city has been dated to 578, and names inscribed into the northern range of seating also seem to be late (i.e. post $-4^{\text {th }}$ c.) in date $e^{24}$. The southern half the hippodrome, however, had been abandoned for two centuries by the time the church was built,

22. Gawlikowski - Musa 1986; Ostrasz 1989; Kehrberg Ostrasz 1997. The early excavations by Müller were largely flawed in both their interpretation and dating: Müller 1938, p. 85-102, with some corrections at p. 100-102.

23. Other examples include Messene, Aphrodisias, Athens, Laodikeia, Aspendos, Perge, Ephesos, Beth Shean, Caesarea, Neapolis. See Welch 1998, p. 565-569; and Saradi 2006, p. 297-298 for partial lists and some analysis of the phenomenon. The conversion at Gerasa went unnoted by its excavators.

24. Ostrasz, 1989, p. 73-74. 


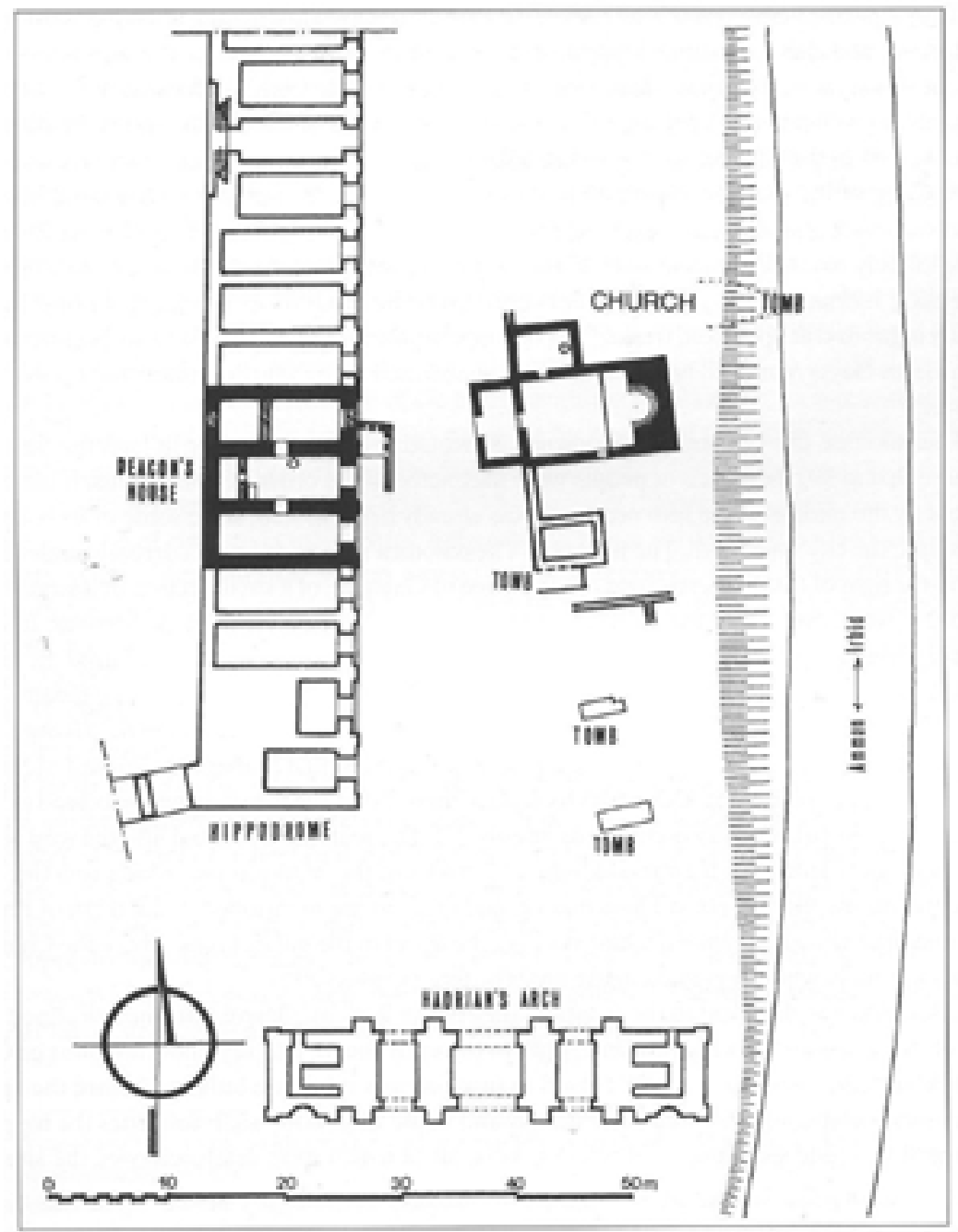

Fig. 8 - Plan, hippodrome, Gerasa, southern end, showing Christian church (M. Gawlikowski and A. Musa, The church of Bishop Marianos, in Jerash Archaeological Project 1981-1983, vol. 1, Amman 1986, fig. 1).

and was instead was used for habitations, ceramic kilns, and as a stone quarry. Indeed, the church was built almost entirely of spolia, both from the circus itself and even from some of $4^{\text {th }}-5^{\text {th }}$ c. buildings that had begun to intrude into its southern half. The church has thus been assumed to have served the population who lived and worked within the circus' southern cavea, and indeed, were the circus-cum-amphitheater functioning, there is no reason it might not have served games-goers as well. It may have alternatively or additionally served as a funerary church for the surrounding necropolis ${ }^{25}$.

25. Two other hippodrome churches should be mentioned in this context, although if only to highlight how little we
Gerasa is thus a salutatory reminder that spectacle buildings were large enough both to host multiple late antique functions simultaneously, and to accommodate sizable human populations and thus to constitute neighborhoods in and of themselves. This may also have been the case at a theater/stadium complex at Ainzanoi in Phyrgia,

know of Christian ritual spaces in hippodromes. A church was found in the hippodrome at Tyre, located on the spina and dated generally to late antiquity but seemingly still in use in the Crusader period: the dating and appearance are extremely sketchy. See Chébab 1969; Chébab 1970, p. $111 \mathrm{ff}$; Chébab 1973. A similarly positioned (and similarly poorly documented) church was built in the hippodrome at Cherchell, where it seemingly occupied one wall of the spina. See Ravoisié 1846, pl. 21-22, 29-30; Leveau 1984, p. 39-40; Humphrey 1986, p. 310. 
in which a late antique chapel was built into the substructures of the stadium's tribunal, similar to the position at Caesarea. ${ }^{26}$ At Ainzanoi, however, there is no suggestion of martyrial use; rather, the chapel may have served the adjacent contemporary settlement that grew up around the great stadium. The phenomenon of spectacle building cum neighborhood, complete with church, persisted well into the Middle Ages as suggested by the well-documented church of Saint-Martín-desArénes at Nîmes, built in the $11^{\text {th }} \mathrm{c}$. to serve that city's large amphitheater-based community, and a similar chapel dedicated to St. Michael in the Arles amphitheater ${ }^{27}$.
That spectacle buildings could also take on saintly, but non-martyrial signification is suggested by the probable late antique church of Saint-Pierreaux-Arénes in the Metz amphitheater. A series of columns arrangedstretching over the cavea and into the arena are said to mark out a cruciform church, which has been dated to the $5^{\text {th }} \mathrm{c}$. by a collection of associated funerary inscriptions as well as ceramic finds ${ }^{28}$. According to Paul the Deacon, the first bishop of the city, one Clement, cleansed the amphitheater of serpents, after which he built his residence and oratory to Saint Peter there ${ }^{29}$. The historicity of this Clement, who is said to have been sent by Christ himself, is dubious, and his deeds as narrated by

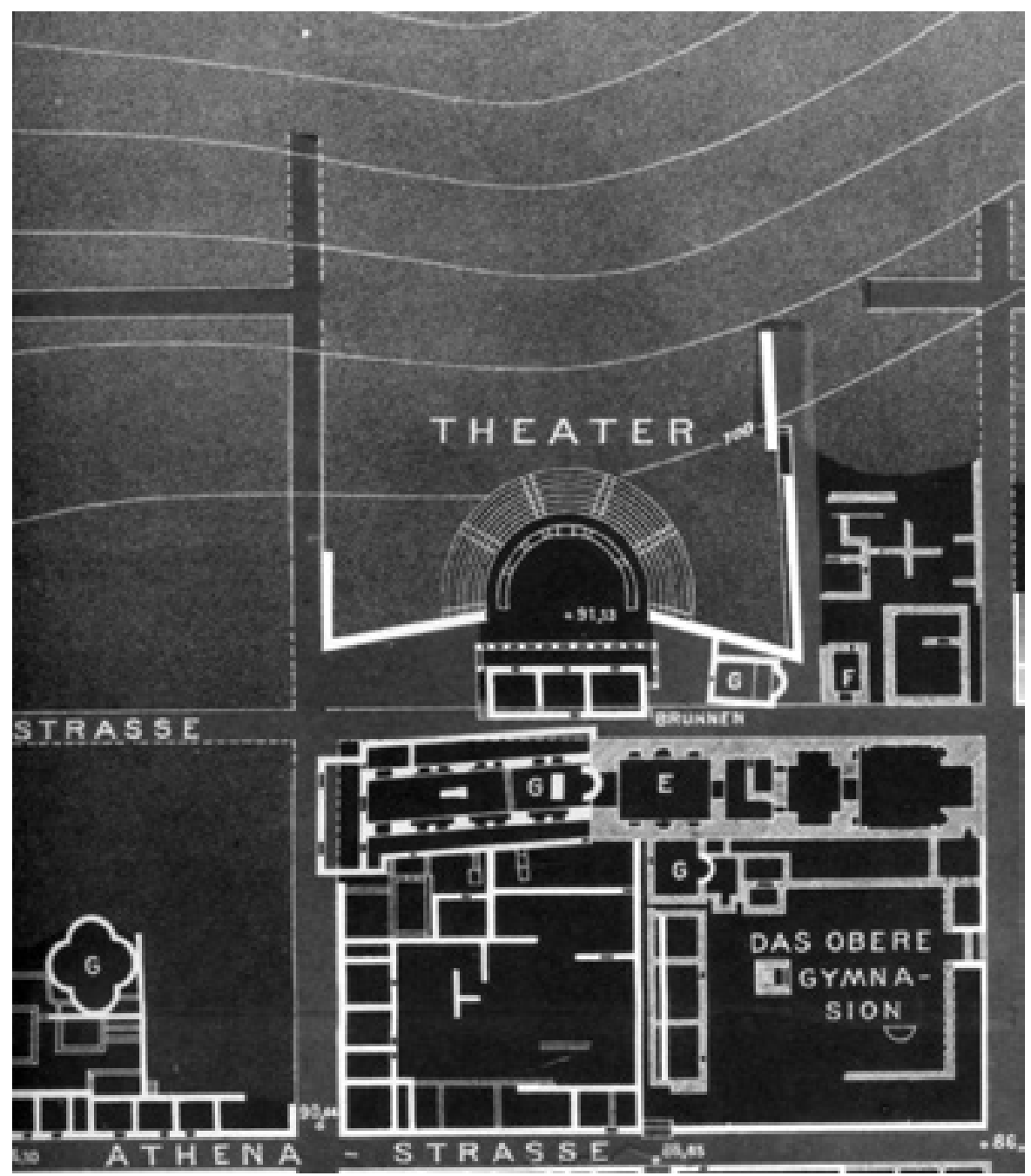

Fig. 9 - City plan, Priene, showing theater with associated chapel. Christian basilica lies to the south (T. Wiegand and H. Schrader, Priene: Ergebnisse der Ausgrabungen und Untersuchungen in den Jahren 1895-1898, Berlin, 1904, overall site plan).

26. Hoffman 1988, esp. 308.

27. Pinon 1979; Formigé 1964, p. 39; Bomgardner 2000, p. 119-20.
28. Heitz 1998.

29. Paul the Deacon, Liber de episcopis Mettensibus, p. 261. 

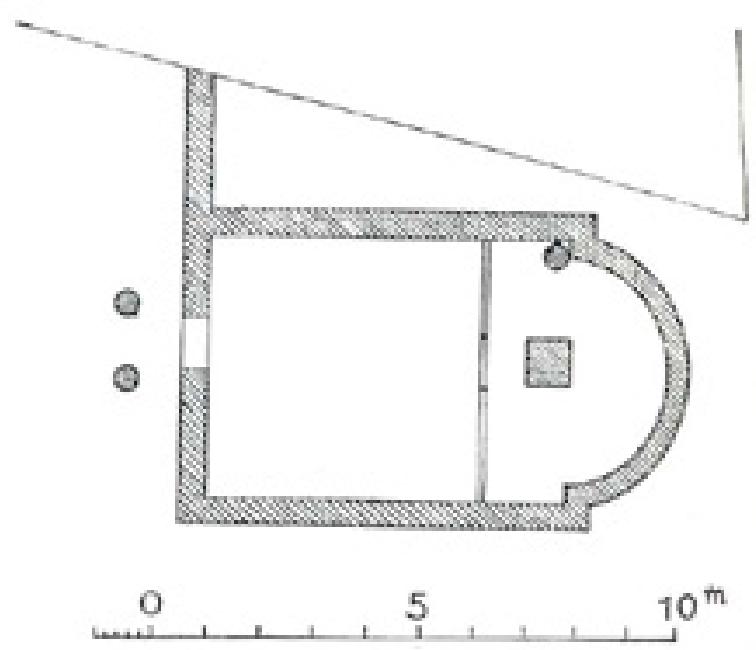

Fig. 10 - Plan, chapel in theater, Priene (T. Wiegand and H. Schrader, Priene: Ergebnisse der Ausgrabungen und Untersuchungen in den Jahren 1895-1898, Berlin, 1904, fig. 598).

Paul the Deacon smack less of late antique memory and more of regional Carolingian concerns around episcopal primacy ${ }^{30}$. Were the building late antique, it may have constituted an early moment in the creation of Clement's legend. In any case, Clement is not said to have been martyred, and the church, if it existed, would thus have marked a spot associated with the saint's life and miracles. The abandoned amphitheater in Paul the Deacon's narrative is not a place of Christian martyrdom, but like so many ruins in western early medieval hagiography, a space of demonic possession and thus a proving ground for the Christian holy man ${ }^{31}$.

If saints need not necessarily be martyrs, graves likewise need not be loci sancti. Two examples of late antique churches built into or beside theaters contain seemingly original graves, but rather than martyr shrines, these seem to be private, probably elite, funerary churches. The two cases are startlingly similar in date, form and positioning. At Priene, a $5^{\text {th }}$ or $6^{\text {th }} \mathrm{c}$. chapel was built into the city's great theater, placed in the eastern parados approaching the orchestra ${ }^{32}$ (fig. 9). A small, single-aisled structure with eastern apse, sanctuary barred by chancel screens and containing a small altar, the church was entered through a western porch, framed by two columns, that faced out into the orchestra beyond. Beneath the floor of the chapel

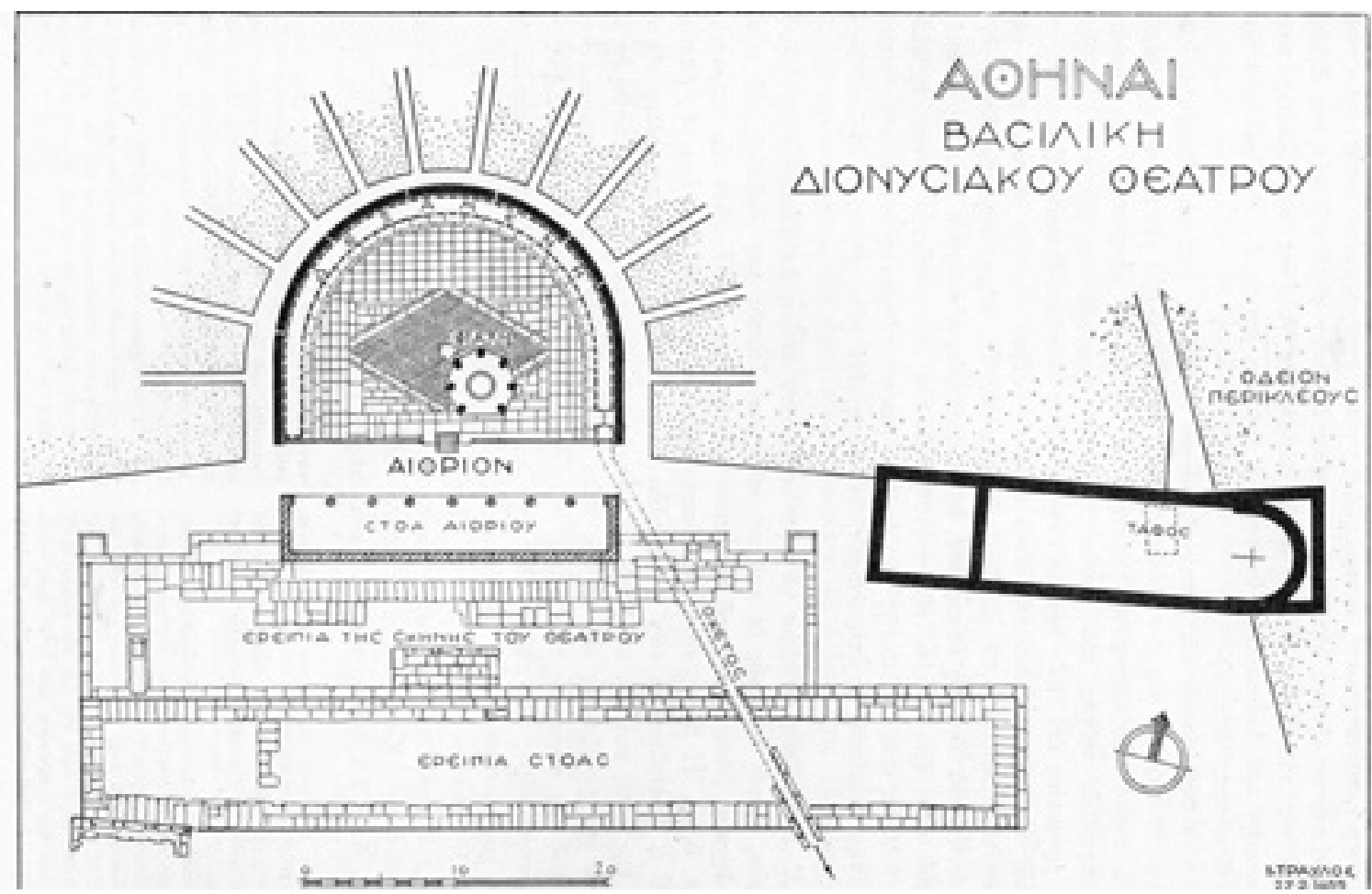

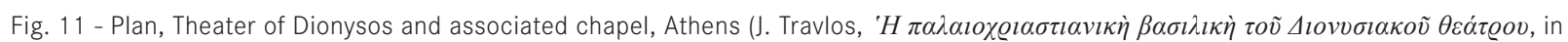

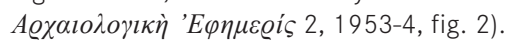




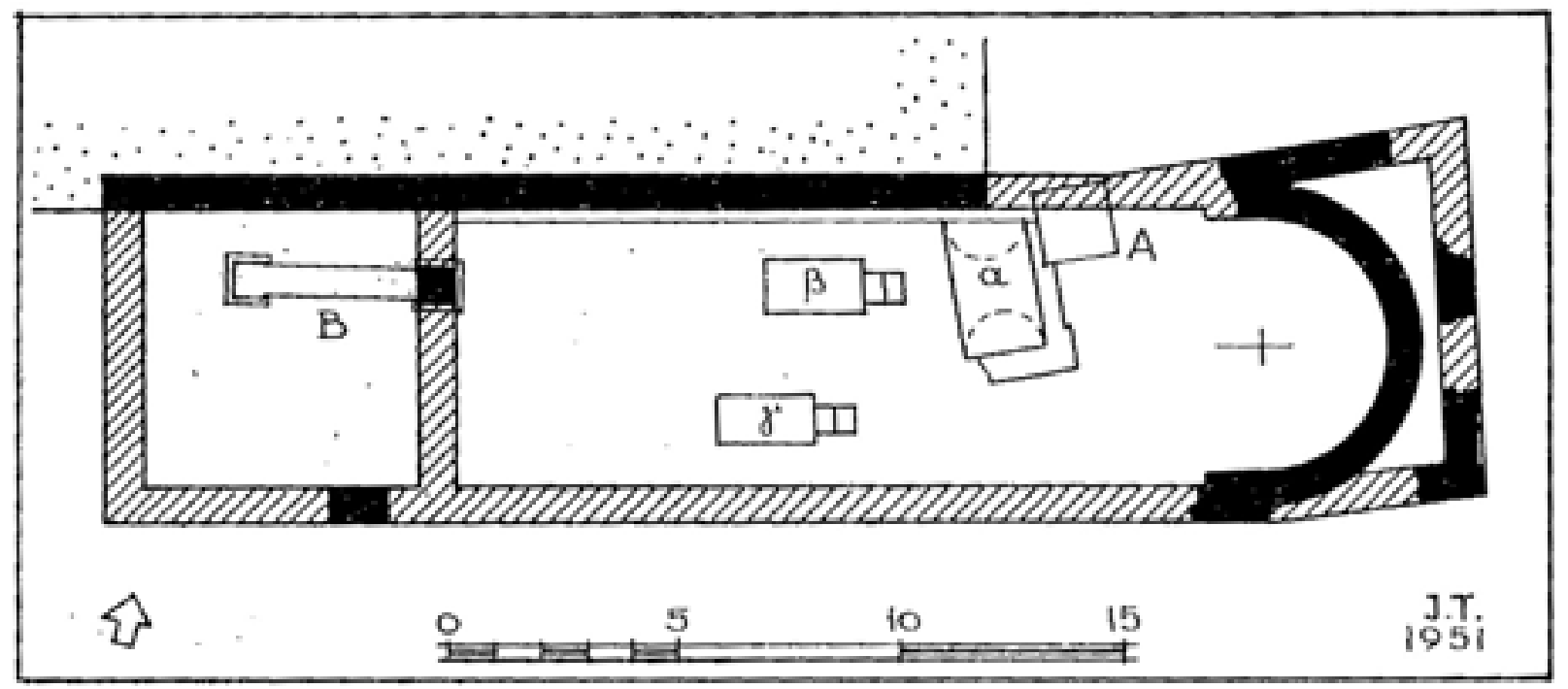

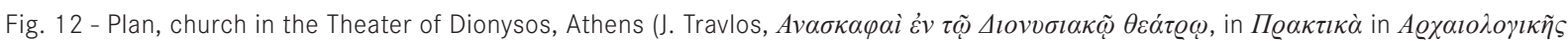
Eтalozias, 1951, fig. 1).

was found the complete skeleton of a man: the location of the grave was not indicated. The theater in this phase seems to have been abandoned and already mined for stone to build the large Christian basilica immediately to the south, a building that also contained many burials beneath its floors.

In Athens at the Theater of Dionysos, another single-aisled chapel was placed in an identical posi-
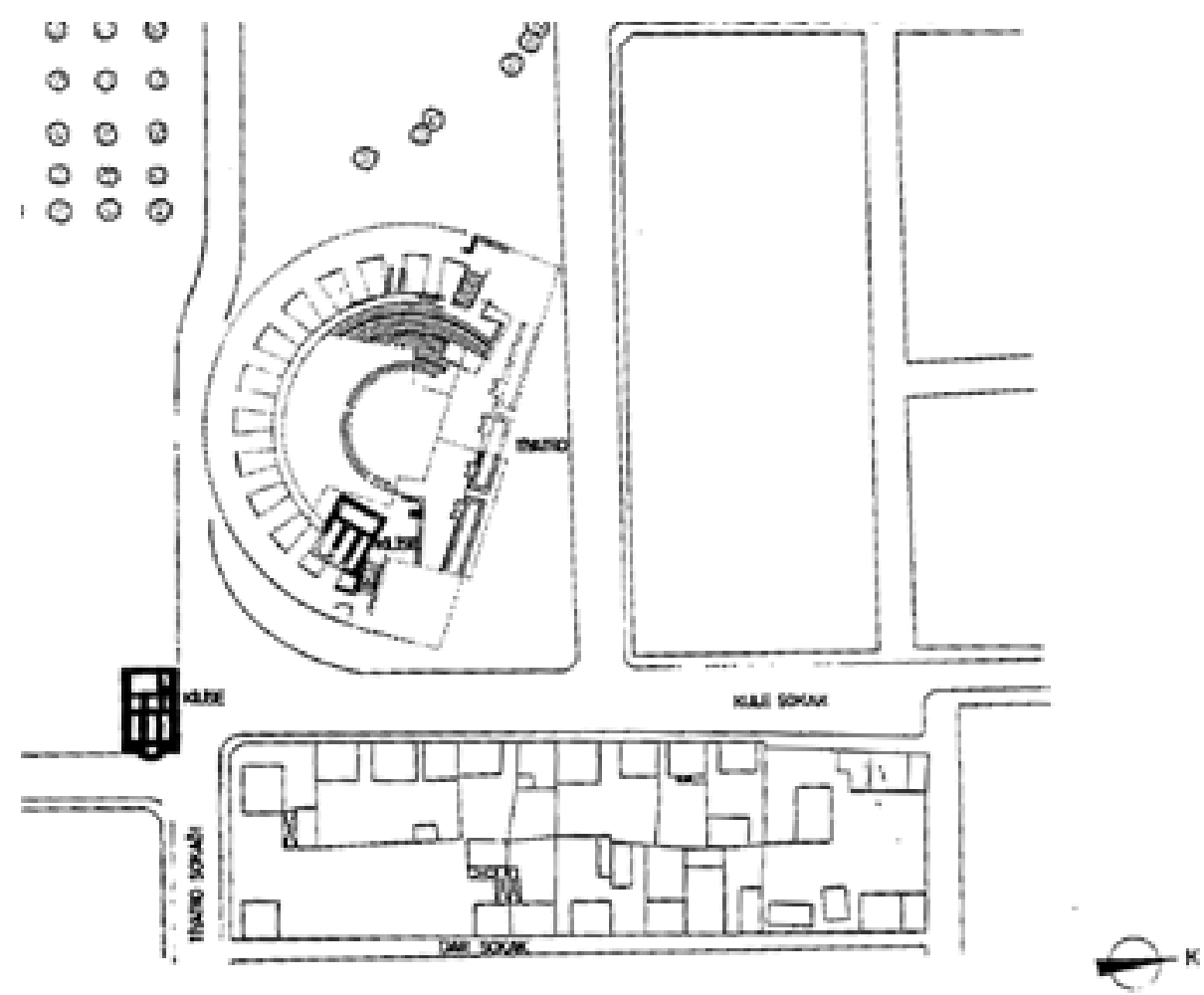

VATET PLAN

Fig. 13 - Plan, theater and church, Nicea, showing adjacent second church and part of cemetery (U. Peschlow, The churches of Nicea/Iznik, in Iznik through the Ages, Istanbul, 2004, fig. 1). 
tion in the eastern parados, re-using its northern wall $^{33}$ (figs. 11-12). Preceded by a narthex rather than a porch, the church contained a vaulted tomb towards its eastern end that reused some ancient architectural elements, and three later Byzantine tombs in the center. The building has been dated variously to the $5^{\text {th }}$ or $6^{\text {th }} \mathrm{c}$. without archaeological basis $^{34}$, while the state of the theater at this time is similarly unclear: cisterns in the orchestra and other graves are dated to the same generally period without archaeological justification ${ }^{35}$.

The use of spectacle buildings for private funerary monuments persisted throughout the Middle Ages. In Nicea, a church built over and re-using the substructures of the theater and dated to the Middle Byzantine period seemingly served as a funerary chapel for the nearby necropolis ${ }^{36}$ (fig. 13). Even more striking are the three chapels built into the amphitheater of Durres, Albania. The largest of these (Chapel 1) was built directly beneath the amphitheater's main viewing box ${ }^{37}$. (figs. 14-15) Frescoes, and later three panels of wall mosaics laid at distinct moments covered walls of the previous amphitheater substructures. While the whole project had been generally assigned a late antique date in the $6^{\text {th }}$ or $7^{\text {th }} \mathrm{c}$., and associated with the martyr Aestios, said in a $9^{\text {th }} \mathrm{c}$. passio to have been stung to death by bees in an unspecified location $^{38}$, new work by the present author have suggested that the project was a small elite funerary chapel of Middle Byzantine date ${ }^{39}$.

At neither Athens, Priene nor Durres was there any archaeological or textual evidence indicating contemporary martyr cult. Rather, all three appear to be private funerary chapels built for an elite individual or family. In all three sites, intramural burial had become common by the $6^{\text {th }} \mathrm{c}$., and thus the notion of an intramural funerary chapel would not have been unusual. Indeed, at Athens, the chapel appears to be part of a larger

33. Travlos 1951; Travlos 1953-1954.

34. Travlos, 1953-1954, suggested a $5^{\text {th }} \mathrm{c}$. date. For a $6^{\text {th }} \mathrm{c}$. date, Frantz 1965, p. 194, 196

35. See Laskaris 2000, p. 77, 153-154.

36. Peschlow 2004.

37. The excavations are summarized in Toçi 1971, p. 40-42; Miraj 1986. The mosaics are described in Cormack 1985, p. 84-85. New excavations in the chapel and surrounds can be found in Bowes - Hoti 2003; Bowes - Mitchell 2009.

38. For a critical review of the hagiography, see Bryer 1994.

39. See Bowes - Mitchell.

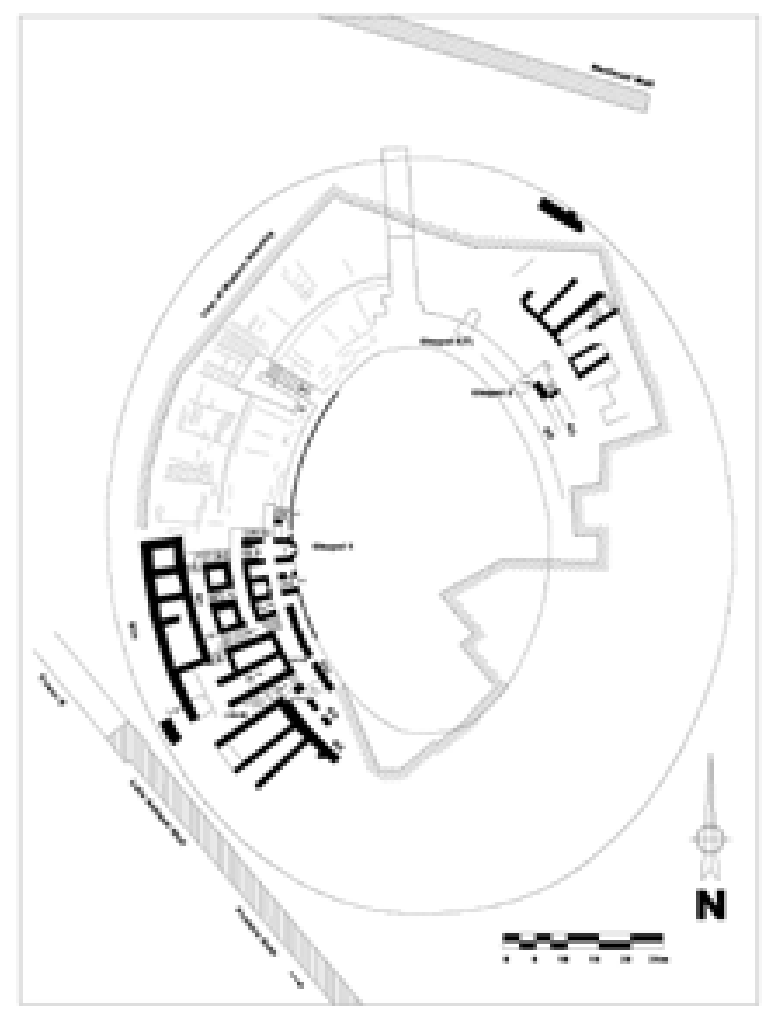

Fig. 14 - Plan, amphitheater, Durres, showing location of chapels (author).

cemetery, while at Durres the Middle Byzantine amphitheater had served as a major necropolis for centuries. The position of all three chapels vis-à-vis their respective monument was probably in part liturgically determined: at Priene and Athens, the parados constituted a ready-made longitudinal space with east-west orientation. At Durres, the western pulvinar and its east-west-oriented substructures were likewise liturgically expedient. And yet, at Priene and Athens the chapels were entered not via the adjacent street, which would have been more convenient, but through the orchestra, while at Durres, access was through the arena and thereafter through the half-filled cavea to the chapel. In all three cases, then, the tiers of seating formed the magnificent, if decaying backdrop to any visitor. This departure from expediency, perhaps, may provide a clue to their meaning. In placing these chapels so, the silent tiers stood witness to the patrons and their families' memory. These buildings, even empty, conjured up the city's multitudes, both past and present, and recalled the spectacles in which acclamation of urban elites 


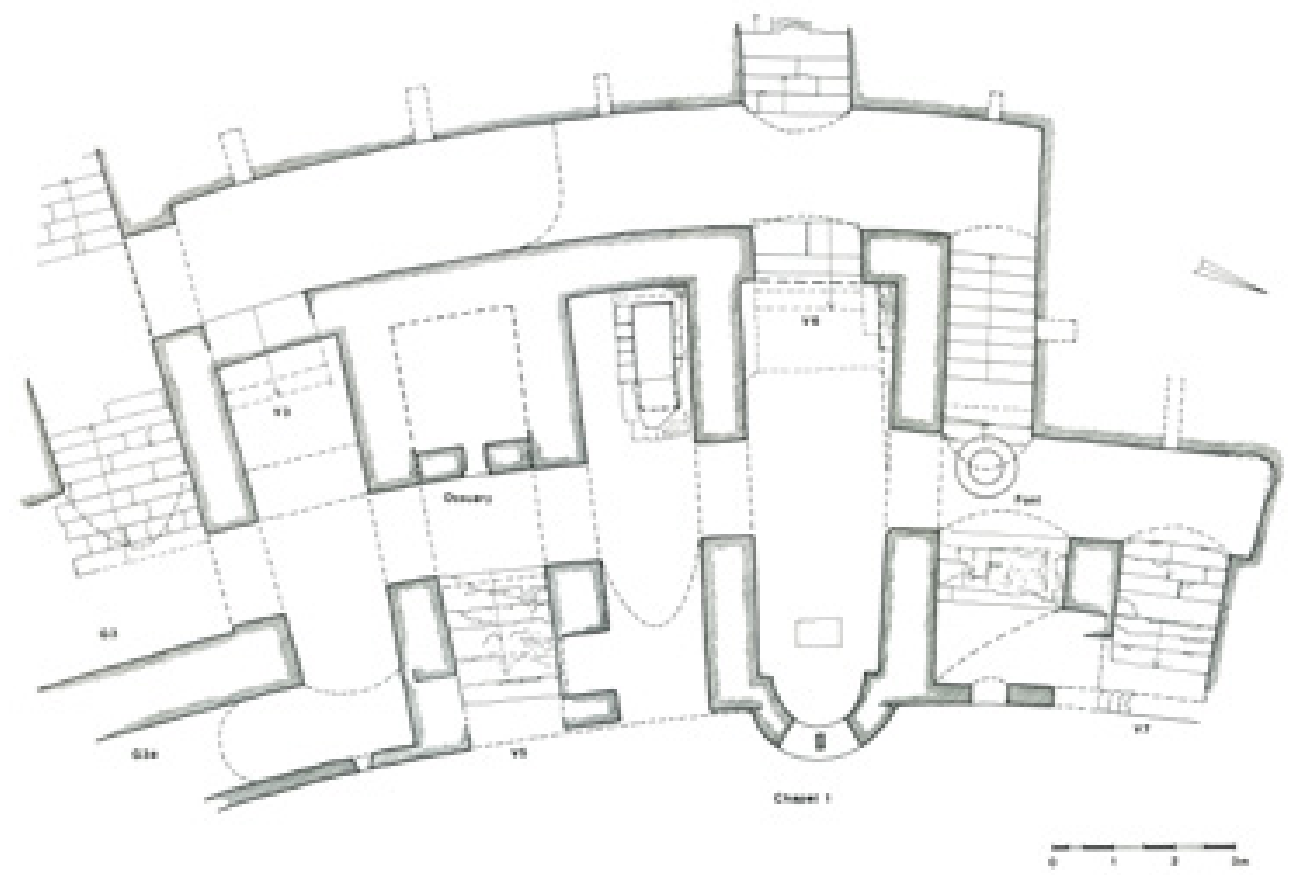

Fig. 15 - Plan, Chapel 1 area, Durres amphitheater (D. Andrews).

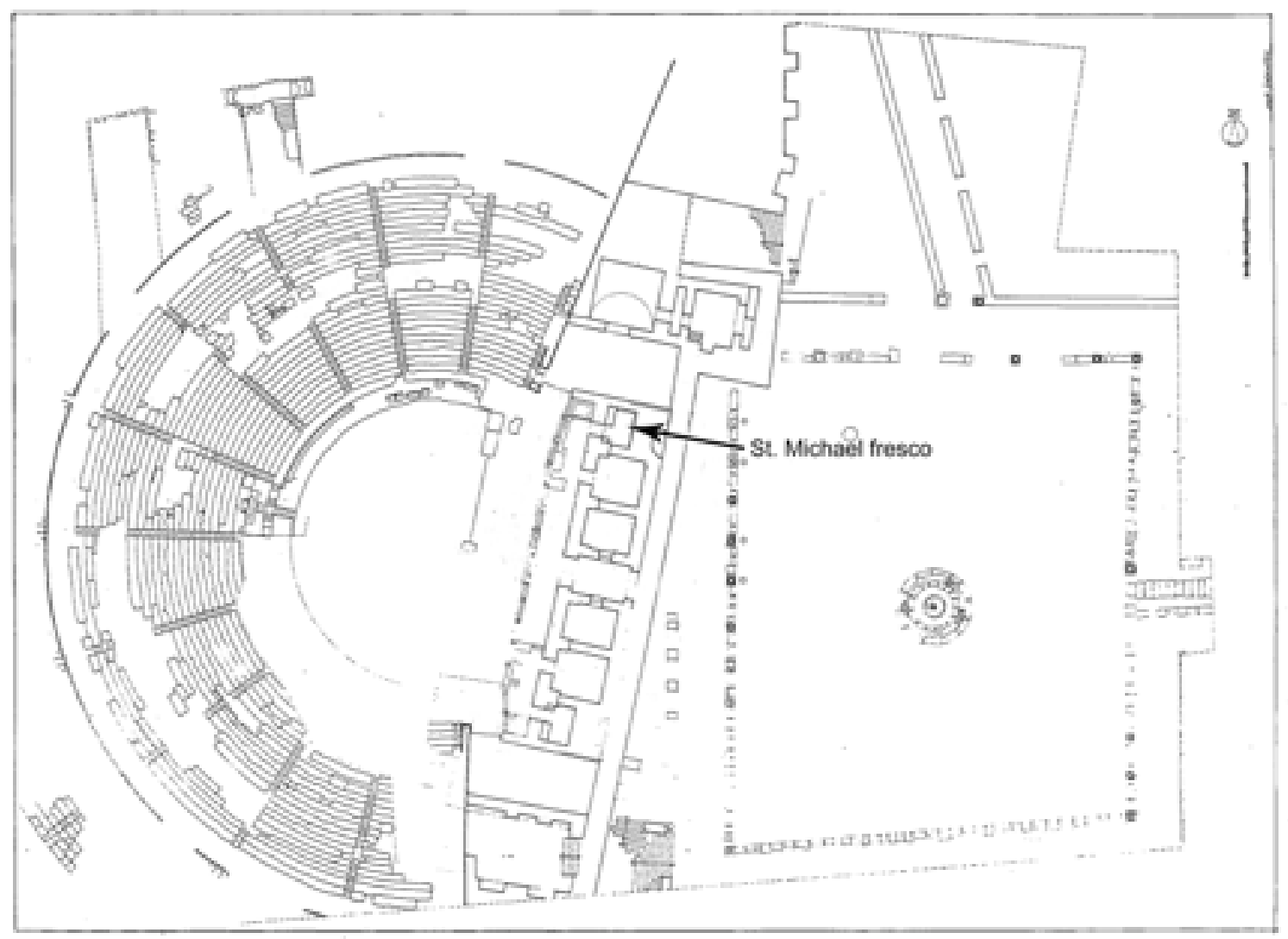

Fig. 16 - Plan, theater, Aphrodisias, with position of Christian frescoes indicated (after K. Erim and R. R. R. Smith, Sculpture from the theatre: a preliminary report, in R. R. R. Smith and K. Erim (eds.), Aphrodisias Papers 2. The Theater, A Sculptor's Workshop, Philosophers and CoinTypes, Ann Arbor, MI, 1991, fig. 1). 
formed part of the performance ${ }^{40}$. At Durres, the location beneath the main viewing box might have additionally conjured up memory of the games' impressarios who would have been seated above. Through placement which was both liturgically expedient and mnemonically suggestive, these late antique elites harnessed the buildings' properties both as ancient urban landmarks and as remembered spaces of communal acclamation and redirected them towards their own commemoration.

Perhaps most at deviance with our vision of Christianity and spectacle is the continued popularity of spectacle, and the maintenance of spectacle buildings for their original use, right through our period. While in general spectacle buildings across the empire ceased to be maintained as such already beginning in the $3^{\text {rd }} \mathrm{c}$., there are important exceptions. Hippodromes are best known for having long late antique lives, but other types of buildings, particularly in major cities, also continued to serve spectacular functions ${ }^{41}$. The nature and popularity of those spectacles naturally changed from the High Empire - from full theatrical dramas to mime and pantomime, from gladiatorial fights to wild-beast hunts ${ }^{42}$. The functional specificity that limited performance type to building - drama in theaters, human combat in amphitheaters - also became more fluid. Thus, those spectacle buildings that continued in use often evolved, sometimes radically: theater orchestras were expanded to hold beast hunts or were outfitted with pools for aquatic spectacle, hippodromes and stadia were shortened into amphitheaters, and hippodromes and amphitheaters were outfitted with machinery for hybrid spectacles like the gymnastics-cumbeast hunts depicted on consular diptychs ${ }^{43}$.

Typically, it has been assumed that the continued roar of the crowds in these still-active buildings took place against the universal condemnation of the Christian church $^{44}$. The patristic refrains against idolatry, adultery and mass-hys- teria allegedly incited by spectacles are depressingly overwhelming. That the raillery is not quite what it would seem has been demonstrated by recent work, which reads the condemnation not as blanket prohibition, but more properly as a tool for Christian bishops to think with - about illusion and the nature of the "real", about the correct Christian community, and about the nature of conversion ${ }^{45}$. Indeed, to imagine a Christian "prohibition" of spectacle is to miss the obvious popularity of spectacles right through our period, as described and even fetishized by the critics themselves.

A tiny handful of archaeological examples suggest an even more starkly different picture, one of Christian ritual collusion and participation in these spectacles. In Constantinople itself, Justinian is said to have built a chapel of Saint Michael in the hippodrome, probably somewhere on the palace side $^{46}$. The Constantinopolitan hippodrome remained not only the venue for beast fights and other entertainments in the capital, it was the foremost space of imperial display, linked to the palace and thus to the most Christian emperor himself. Nothing remains of Justianian's hippodrome chapel, but two relatively convincing extant examples suggest that this was not an isolated, imperial exception. In the theater at Aphrodisias, Christian paintings in the north room of the scena may date to the early decades of the $6^{\text {th }} \mathrm{c}$., a date when epigraphic remains suggest the theater was still used for theatrical presentations ${ }^{47}$ (figs. 16-17). The room was decorated with images of the angels Michael and Gabriel, and perhaps other figures, which were probably positioned on the back and eastern walls ${ }^{48}$. While some enigmatic narrow benches line the room, there is no evidence for cult practice in this room - no altar and certainly no martyrial functions - and thus it has been suggested that the images may have served as votives or for use in personal prayer ${ }^{49}$. Given the images' location in a room off the stage,
40. See Cameron 1976; Lim 1999.

41. E.g. Retzleff 2003.

42. Among a sizable bibliography, see Ville 1960; Cameron 1973; Markus 1979; Lim 1997; Webb 2009, p. 24-43; Dodge 2011, 69-78.

43. See Retzleff 2003; Olovsdotter 2005.

44. See Webb 2009; Lim 1997; Ville 1960.
45. C.f. Webb 2009; Leyerle 2001; Lim 2003.

46. Exemplum rescripti fidei Flaviani archiepiscopi (Mansi 8, p. 833 B); Janin 1953, p. 355.

47. On the use of the building in late antiquity, see Roueché 1991, p. 99-108. Figural paintings were also found in the south scena room, but were insufficiently preserved to understand their subject matter.

48. Cormack 1991.

49. Cormack 1991, p. 115. 


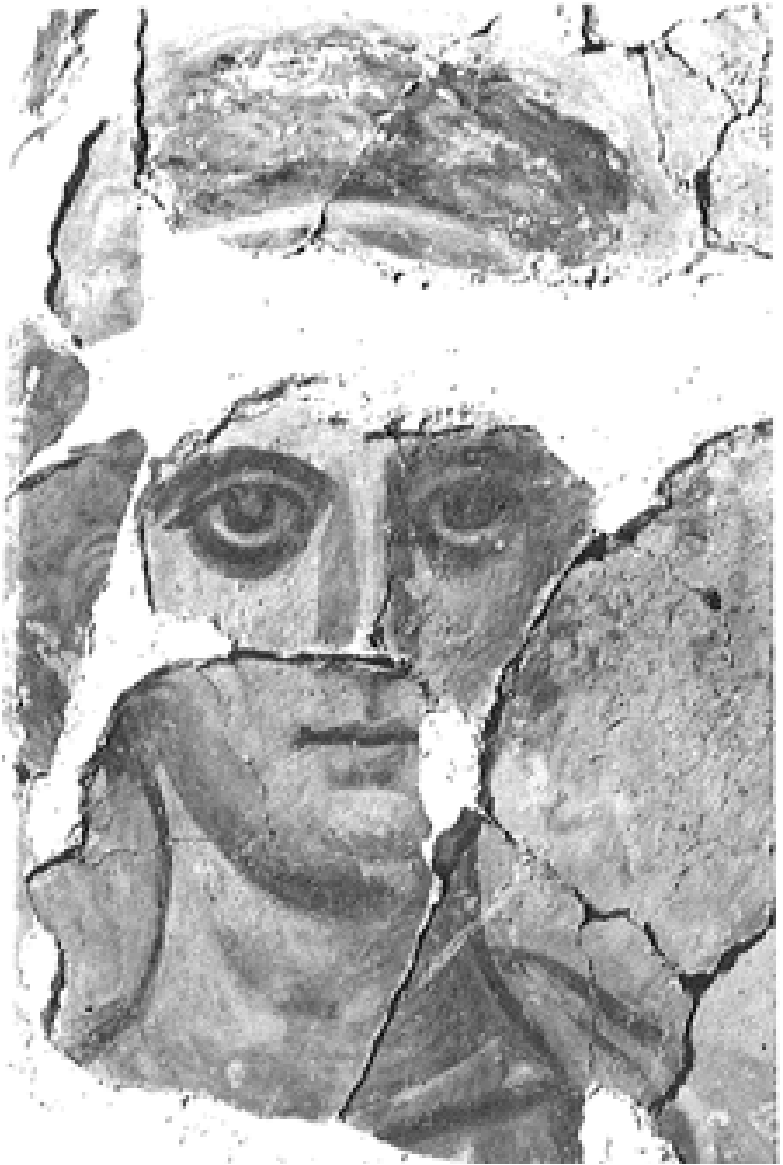

Fig. 17 - Fresco, image of St. Michael from north scena room (R. Cormack, The wall-painting of St. Michael in the theater, in R. R. R. Smith and K. Erim (eds.), Aphrodisias Papers 2. The Theater, A Sculptor's Workshop, Philosophers and Coin-Types, Ann Arbor, MI, 1991, fig. 9).

it is not impossible to imagine a theater performer as their audience or even patron.

The Christian installations in the theater at Side, in Pamphylia may have also taken place in a still-thriving building (fig. 18). Here the Romanperiod theater was repaired at some point in late antiquity, perhaps during the $5^{\text {th }}$ or $6^{\text {th }} \mathrm{c}$. when the city was capital of Pamphylia Secunda. Some of the arches and supporting piers of the western façade were rebuilt, mosaics floors were laid in the galleries, and two large inscriptions seemingly place above them, proudly describing the renovations and their donors. ${ }^{50}$ Two chapels were also

50. Mansel 1963, p 140-141; Mansel 1978, p. 210-213; Mansel 1964. These read, respectively: "This great work, whose praise extends over the whole world, Fronto has rebuilt, together with the proconsul, as ornament to his reign" inserted into the eastern and western corners of the cavea beneath the podium seating. Only the western of these was excavated, its barrel-vaulted interior found to be covered with frescos and separated from the orchestra by a wall pieced by windows and a door. The excavator attributed both the reconstruction and the chapels to the same $5^{\text {th }}-6^{\text {th }}$ c. date, albeit without supporting evidence. Together with the discovery of some crosses as well as the title prepositus inscribed on the seating, the later presumed to be a priestly title, he suggested the whole amphitheater was now a holy space used for Christian ritual. The fact that the Synaxarion of Constantinople attributes to Side a group of Diocletianic martyrs who were put to death after attacking images in a temple, seemed to confirm this hypothesis ${ }^{51}$. As attractive as this idea is, the connections are circumstantial at best. The evidence of the Synaxarion is unconvincing: nowhere does it mentions the theater as the site of martyrdom, and in any case it cannot be dated earlier than the collection's compilation in the $9^{\text {th }}$ or $10^{\text {th }} \mathrm{c}$., many centuries after the chapels themselves were abandoned. Rather, as at Aphrodisias, it seems most likely that theater and chapels functioned together in the later $5^{\text {th }}$ or $6^{\text {th }} \mathrm{c}$. The restoration donor inscriptions make no mention of martyrs and a Christian context is provided only by the flanking inscribed crosses that appear everywhere in public inscriptions of the era. The structural nature of these modifications, plus the new mosaic floors and the inscriptions in the seating all suggest the continued use of the theater as a place of spectacle. Whether or not the two chapels go with this later phase of use is unclear, as no evidence is provided for their chronology, but the possibility seems likely.

Christian sources, so blisteringly critical of theatrical performance, are little help in understanding how these Christian theater spaces might have

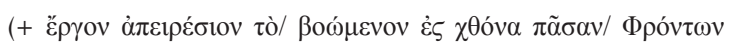

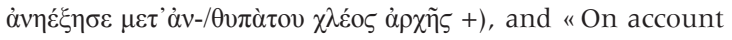
of the funds provided by reason of the earlier proconsuls and patricius, the city has reconstructed the piers and the arches, which are found under the inscription" $(+\dot{\eta}$

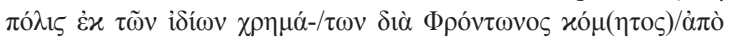

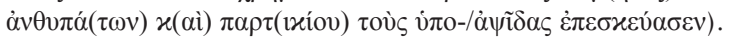
Other more fragmentary inscriptions seem to ascribe the repairs to a "thespian" Theodoros and his son.

51. Synaxarium Ecclesiae Constantinopolitanae, Delehaye 1902, col. 860-861. 
been used, and we have only the obvious popularity of the spectacles themselves and the archaeology to help us. The theaters of the Greek east that continued to be used also continued to be points where urban communal identity was performed and reaffirmed. In the Christian-majority world of the $6^{\text {th }}$ c., urban identity meant Christian identity, and it should hardly be surprising that blessings, protection and approbation of the Christian god should be called upon - both for building itself as urban landmark, and for the performances it hosted. The location of the Christian spaces in both theaters is interesting in this regard: the paired chapels at Side, placed beneath the eastern and western corners of the seating, suggest an attempt to frame the space in holy power, while some fragmentary remains in the south scena room at
Aphrodisias, which may or may not be Christian, paralleling those in the north room, might hint at a similar kind of flanking maneuver ${ }^{52}$. The Christian spaces in both theaters might thus be interpreted as "hot-spots», blanketing the space with Christian projection and thus ensuring God's sanction for the events within.

\section{MAKING SENSE OF ABSENCE: SPECTACLE BUILDINGS AS CHRISTIAN NON-SPACES}

Even accounting for the accidents of preservation and the vagaries of early excavation, the examples outlined here are striking both for their paucity and for the absence of evidence consistently connecting the commemoration of martyrs with spectacle buildings. The examples we do have

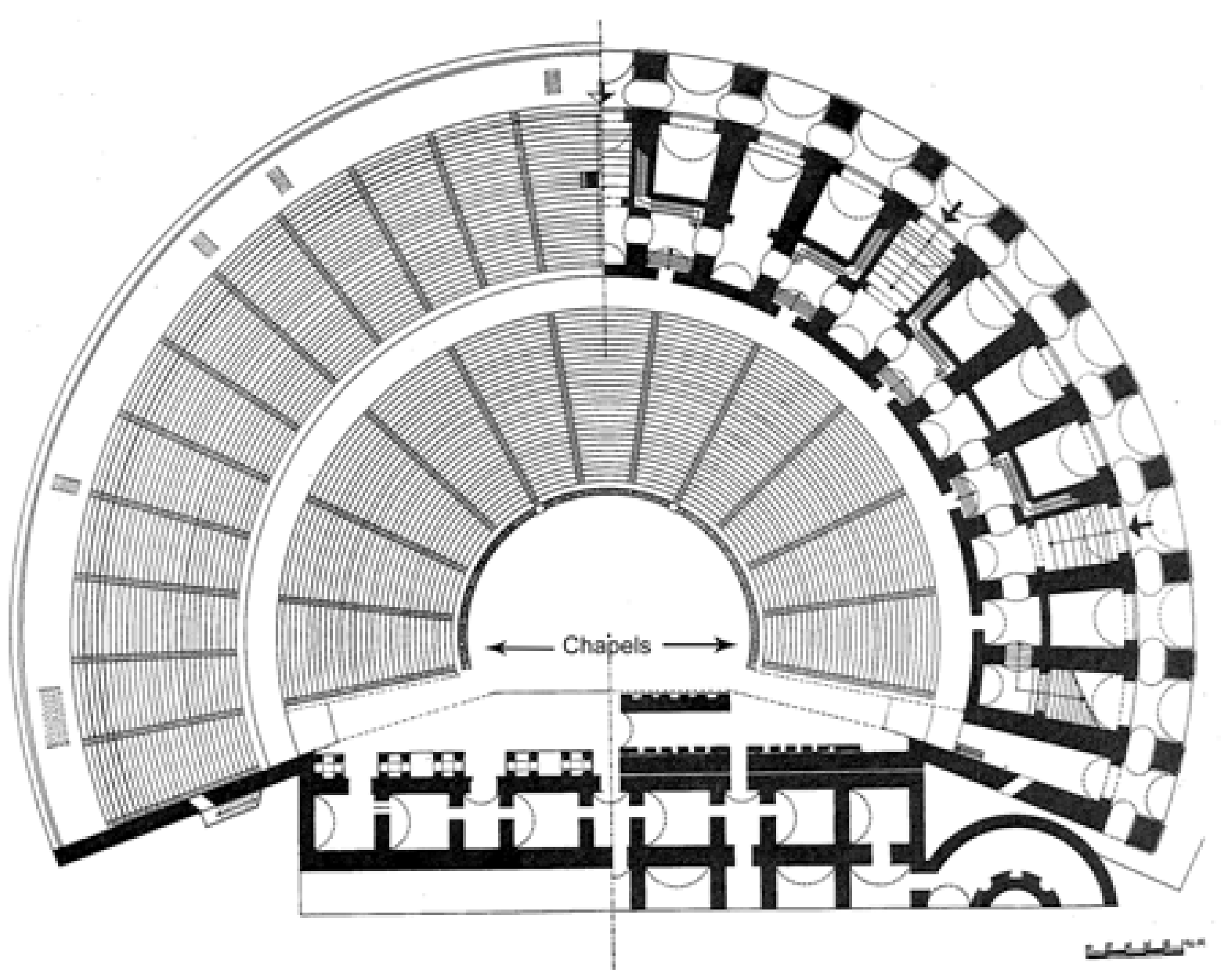

Fig. 18 - Plan, theater, Side, showing location of two chapels (after A. M. Mansel, Side. 1947-1966 yillari kazilari ve araştirmalarinin sonuçlari, Ankara, 1978, fig. 208). 
point instead to a broader range of Christian interventions in such buildings than simply martyrial cult, and while the overall picture is one of general disinterest in spectacle buildings as a specific space that required "Christianizing".

One might object that the reason that there are so few convincing examples of martyr shrines in spectacle buildings is not only the poor archaeology, but the fact that some kind of textual evidence is necessary, or at least helpful, to identify a church as martyr's shrine. It is interesting, in this regard, that the textual evidence is similarly lacunose when it comes to identifying spectacle buildings as places of martyrdom. Most early passiones provide very little detail as to the exact place of the martyr's death. Rather, when descriptions of physical topography appear, as they do in the stories of the Roman martyrs in particular, they instead linger perhaps over the location of the trial but even more insistently over the place (or places) of burial. Hippolyte Delehaye long ago noted this phenomenon in his study of the Colosseum, another spectacle building which was never associated with any particular martyr, and only gained widespread Christian meaning through the intervention of Clement $X$ in the late $17^{\text {th }}$ C. $^{53}$. Delehaye noted that not only was the Colosseum never unambiguously listed as a martyr site in the gesta martyrum of the Roman martyrs, but also that very few Roman passiones list a specific building as a place of death. Most are mute on the place of execution, while others mention the Tellus on the Esquiline, one possible location of the urban prefect's office. Even the early, most spectacle-focused passiones, like the martyrdom of Polycarp, or Perpetua and Felicitas, which relate the martyr's responsorial relationship with the spectacle crowd, name the place of death only in passing as "the stadium » or " the amphitheater ». ${ }^{54}$ In very general terms, then, and like the archaeology, the evidence of the late antique passiones points against a widespread interest in defining martyrdom and even subsequent martyr cult around the martyr's place of death, and thus around martyrial commemoration in spectacle buildings.

53. Delehaye 1897.

54. Passio S. Polycarpi, 9.1 ; Passio Ss. Perpetuae et Felicitatis, 18.
As the brief tour of the archaeology above suggests, spectacle buildings had particularly long and particularly diverse late antique lives. The use of spectacle buildings for fortifications, potteries, habitations, graveyards, not to mention the continued use for their original purposes, not only suggests that they experienced a diversity of fates in late antiquity, but also that they would have had layered, rather than singular meanings. A building type that might serve as one's home, the neighborhood shop, or a refuge in times of danger ceased to be a site of specific memory, and instead took on local and/or condition-specific meanings, layered along with their spectacular ones. Martyrial memories, even if they were present, would thus have vied with other kinds of more quotidian or more immediate experience.

We might even go further, however, and suggest that martyrial memory was in general not spatially fixed. The disinterest in a topography of martyrial death, as evident in both the material and the hagiographic records, might seem to indicate that late antique people did not particularly care where precisely martyrs met their death. Put more correctly, we might suppose that the space of death never formed part of the late antique discursive apparatus of "martyr-making $»^{55}$.

However, to say that the space of death played no role in martyrial construction is to miss an important spatial component of nearly all late antique hagiography - namely the space of the martyrial body. It was the body, to the exclusion of that body's architectural spatial surroundings, that was the spatial vessel into which martyrial meaning was poured. As recent scholarship has noted, it was the body that was used to make a mockery of Roman imperial hierarchies; it was the body that was the site of the gender transformations that martyrs experienced as part of their passage out of the quotidian realm, it was through the martyrial body that Christian arguments about correct sacrifice were written, and it was the martyr's mobile, even divided body in the form of relics that the universal and ubiquitous power of God was made manifest ${ }^{56}$. The body, of course, is

55. On which see Grig 2004.

56. See respectively on the inversion of hierarchical structures: Perkins 1995, p. 104-123; on gender transformation and passivity: Shaw 1996; Burrus 1995; on sacrifice: Castelli 2001. 


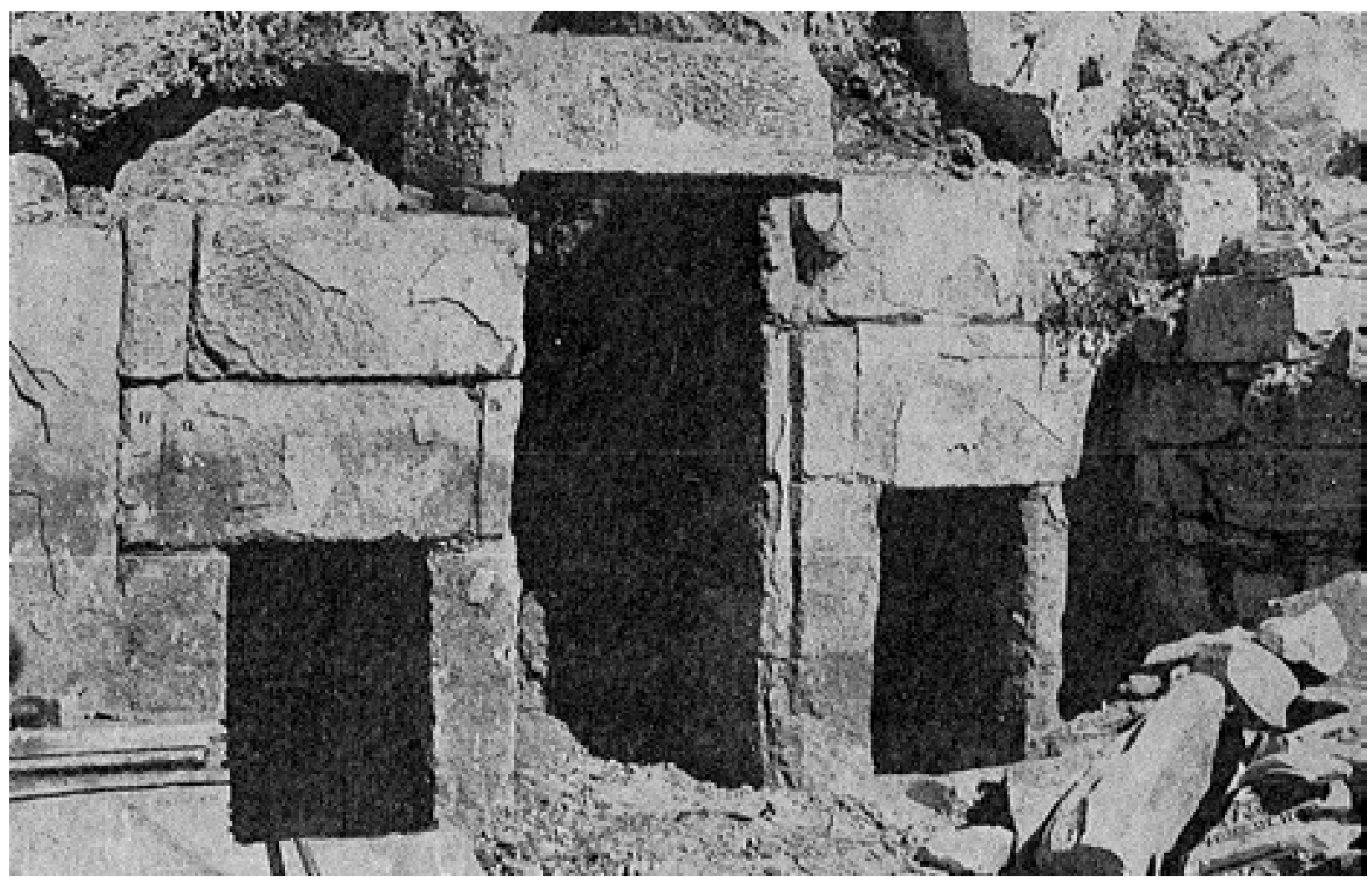

Fig. 19 - View of western chapel, theater, Side (A. M. Mansel, Side. 1947-1966 yillari kazilari ve araştirmalarinin sonuç/ari, Ankara, 1978, fig. 239).

a space - indeed, it is the body that calls space into being by directing and orienting our perception of the world ${ }^{57}$. The discursive, textually constructed and remembered martyrial body is likewise a space, the physical vessel for collapsed history, containing the Christ of the past and the martyr of the present ${ }^{58}$. The spatial qualities of that memory and history-laden body were made most insistent through its movable and partible qualities: the martyr's body was a portable holy space whose parts contained the power of the whole ${ }^{59}$. This is why the same hagiographies that are so reticent on matters of urban topography dwell so insistently on the martyrial body - its torture, its eroticized sexuality, and its perambulations after death to grave site and relic distribution - for it is the body which is the true mis-en-scène of martyrdom.

I would argue that this emphasis on the martyrial body as the exclusive space of martyrial memory left the built environment, particularly the spectacle buildings where some martyrs met their death, in something of a lurch. Like modern hospitals or movie houses, spectacle buildings were vessels where matyrial memories may have been made, but which were themselves left untouched by those memories. In respect to Christian martyrial memory, they were not unlike Marc Augé's non-spaces - vessels that lack the "stickiness" of true spaces and thus fail to accrue their relational, historical and memory-laden qualities ${ }^{60}$. Obviously, spectacle buildings in late antiquity are not true non-spaces; as witnessed by their reuse as graveyards and the particular placement of churches in those graveyards, their histories continued to be relevant and re-imagined. But as specifically martyrial memory sites, they were left spatially "empty" by a thought world that located such spaces instead within the martyr's body.

58. C.f. Smith 1987, who sees this collapse as occurring through rituals, rather bodies.

59. C.f. Brown 1981, p. 59 
If this argument is broadly true for late antiquity, one wonders when things changed, that is, when the spectacle building became, as it is for us, the über-site of Christian martyrial memory. This is a problem that is beyond the scope of this article, but it is probably much later than we think, perhaps not until the early modern period. It is only in the $17^{\text {th }} \mathrm{c}$. that the Coloseum in Rome is reimagined in this way. Similarly, in the Durres amphitheater, next to the Middle-Byzantine Chapel 1, a small ossuary was built in the $16^{\text {th }} \mathrm{c}$. to hold hundreds of bones, almost certainly from their graves in the surrounding amphitheater necropolis ${ }^{61}$. Why these graves should have been enshrined so is interesting to contemplate: were they regarded as martyrs because of their location in the ruined remains of an amphitheater? Did the recent takeover of the city by Ottomans and the concomitant reversion of Christianity to a minority religion encourage a reimagining of the faith's persecuted past? It is noteworthy in any case that the best evidence for martyrial commemoration at Durres is so very late.

\section{Bibliography}

AASS = Acta Sanctorum quotquot toto orbe coluntur (Anvers, 1643-).

Augé 2008 = M. Augé, Non-Places. An Introduction to SuperModernity, trans. J. Howe, $2^{\text {nd }}$ ed. London-New York, 2008.

Bardy 1967 = Eusèbe de Césarée, Histoire ecclésiastique. Livres VIII-X et les Martyrs en Palestine, Paris, 1967 (Sources Chrétiennes, 55)

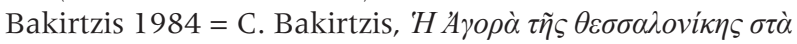

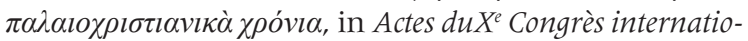
nal d'archéologie chrétienne, Thessalonique, 1980, Vatican City, 1984, vol. 2, p. 5-18.

Bayliss $2004=$ R. Bayliss, Provincial Cilicia and the Archaeology of Temple Conversion, Oxford, 2004.

BHL = Bibliotheca Hagiographica Latina, éd. socii Bollandiani, 2 vol., Bruxelles, 1898-1901 (Subsidia Hagiographica, 6).

BHL Suppl. = Bibliotheca hagiographica latina antiquae et mediae aetatis, novum supplementum, Bruxelles, 1986.

Bomgardner $2000=\mathrm{D}$. L. Bomgardner, The Story of the Roman Amphitheater, London, 2000.
CONCLUSIONS : SANT'AGNESE IN AGONE IN CONTEXT

Sant'Agnese in Agone is thus, at least in comparative perspective, both atypical and typical. It is atypical in that it forms one of the few examples of martyrial commemoration inside a Roman spectacle building. It is typical, however, in that this tradition seemingly did not develop in late antiquity, but in the Middle Ages or later, a delay reflected and perhaps in part encouraged by the ambiguous textual tradition naming Agnes' specific place of martyrdom as the Stadium of Domitian. During that time the stadium had evolved other uses, including, as it is now clear, an intra-mural necropolis. In determining how the stadium came to be specifically associated with Agnes and in what context the medieval oratory was built, the papers in this volume are addressing the genuine complexity surrounding the so-called "Christianization" of spectacle buildings and the construction of martyrial memory.

Bowes - Hoti 2003 = K. Bowes and A. Hoti, An amphitheatre and its afterlives: survey and excavation in the Durres amphitheatre, in Journal of Roman Archaeology, 16, 2003, p. 380-394.

Bowes - Mitchell $2009=\mathrm{K}$. Bowes and J. Mitchell, The main chapel of the Durres amphitheater: Chronology and function, in MEFRA, 121-2, p. 569-595.

Bowes $2006=\mathrm{K}$. Bowes, The Dürres amphitheater: Archaeology and memory, in L. Bejko and R. Hodges (eds.), New Directions in Albanian Archaeology. Studies Presented to Muzafer Korkuti, Tirana, 2006, p. 242-256.

Brogiolo - Ward-Perkins 1999 = G. P. Brogiolo,B. WardPerkins (eds.), The Idea and Ideal of the Town between Late Antiquity and the Early Middle Ages, Leiden, 1999.

Brogiolo - Christie - Gauthier $2000=$ G. Brogiolo, N. Gauthier and N. Christie (eds.), Towns and their Territories between Late Antiquity and the Early Middle Ages, Leiden, 2000.

Brown $1981=$ P. Brown, The cult of the Saints: its rise and function in Latin Christianity, London, 1981.

Bryer $1994=$ A. Bryer, Saint Asteios and the amphitheatre

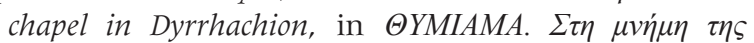

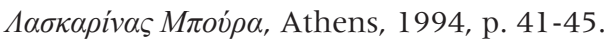


Burrus $1995=$ V. Burrus, Reading Agnes: The Rhetoric of Gender in Ambrose and Prudentius, in Journal of Early Christian Studies, 3, 1995, p. 25-46.

Cameron $1973=$ A. Cameron, Porphyrius the Charioteer, Oxford, 1973.

Cameron 1976 = A. Cameron, Circus Factions: Blues and Greens at Rome and Byzantium, Oxford, 1976.

Cantino Wataghin 1999 = G. Cantino Wataghin, ....Ut haec aedes Christo Domino in Ecclesiam consecretur. Il riuso cristiano di edifici antichi tra tarda antichità e alto medioevo, in Ideologie e pratiche del reimpiego nell'alto medioevo. Settimane di Studio del Centro Italiano di Studi sull'Alto Medioevo, XLVI, Spoleto, 1999, p. 673-750.

Castelli 2001 = E. Castelli, Martyrdom and Memory. Early Christian Culture Making, New York, 2004, p. 50-68; G. Clarke, Translating relics: Victricius of Rouen and fourth century debate, in Early Medieval Europe, 10, 2001, p. 161-176.

Chébab 1969 = B. Chéhab, Tyre, Beirut, 1969.

Chébab $1970=$ Tyre Through the Ages, Beirut, 1970 .

Chébab 1973 = Le cirque du Tyr, in Archeologia, 55, 1973, p. 16-20.

Cormack $1985=$ R. Cormack, Writing in Gold: Byzantine Society and its Icons, London, 1985.

Cormack $1991=\mathrm{R}$. Cormack, The wall-painting of St. Michael in the theater, in R. R. R. Smith and K. Erim (eds.), Aphrodisias Papers 2. The Theater, A Sculptor's Workshop, Philosophers and Coin-Types, Ann Arbor, MI, 1991, p. 109-122.

Cureton $1868=$ Eusebius of Caesarea, History of the Martyrs in Palestine, London, 1868.

De Certeau $1984=$ M. de Certeau, The Practice of Everyday Life, trans. S. Randall, Berkeley, 1984 (French lst edition 1980).

Deichmann 1939 = F. Deichmann, Früchristliche Kirchen in antiken Heligtümern, in Jahrbuch des Deutschen Archäologischen Instituts, 54, 1939, p. 105-136.

Delehaye $1897=\mathrm{H}$. Delehaye, L'amphithéatre Flavien et ses environs dans les textes hagiographiques, in Analecta Bollandiana, 16, 1897, p. 209-252.

Delehaye 1902 = H. Delehaye ed., Synaxarium,Ecclesiae Constantinopolitanae e codice sirmondiano nunc berolinus, Bruxelles, 1902.

Dodge $2011=\mathrm{H}$. Dodge, Spectacle in the Roman World, London, 2011.

Dörpfeld - Reisch 1896 = W. Dörpfeld, E. Reisch, Das griechische theater. Beiträge zur geschichte des Dionysos-theaters in Athen und anderer griechischer theater, Athens, 1896.

Dyggve 1933 = E. Dyggve, Recherches à Salone, vol. 2, Copenhagen, 1933.

Formigé 1964 = J. Formigé, L'amphithéatre d'Arles, in Revue archéologique, 2, 1964, p. 25-41, 113-163.

Fowden $1978=$ G. Fowden, Bishops and temples in the eastern Roman empire, in Journal of Theological Studies, 29, 1978, p. 53-78.

Franz $1965=$ A. Frantz, From Paganism to Christianity in the Temples of Athens, in Dumbarton Oaks Papers, 19, 1965, p. 187-205.

Fumagalli $1994=$ V. Fumagalli, Landscapes of Fear. Perceptions of Nature and the City in the Middle Ages, Oxford, 1994.
Gawlikowski - Musa 1986 = M. Gawlikowski, A. Musa, The church of Bishop Marianos, in Jerash Archaeological Project 1981-1983, vol. 1, Amman 1986, p. 137-153.

Gersht $1996=\mathrm{R}$. Gersht, Representation of deities in the cults of Caesarea, in A. Raban, K. Holum (eds.), Caesarea Maritima. A Retrospective after Two Millennia, Leiden, 1996, p. 305-326.

Gibbon 1984 = E. Gibbon, Memoirs of My Life, ed. B. Radice, London, 1984.

Godoy 1999 = C. Godoy Fernández, Basílica de l'amfiteatre de Tarragona, Del Romà al Romànic, Barcelona, 1999.

Grig 2004 = L. Grig, Making Martyrs in Late Antiquity, London, 2004.

Hanson 1978 = R. Hanson, The transformation of pagan temples into churches in the Early Christian centuries, in Journal of Semitic Studies, 23, 1978, p. 257-267.

Heitz 1998 = C. Heitz, Metz: Église Saint-Pierre-aux-Arénes, in N. Duval (ed.), Les premiers monuments chrétiens de la France, Paris, 1998, p. 248-251.

Hoffman 1988 = M. Hoffman, Aizanoi 1978: Arbeiten in Stadion, in Kazi Sonuclari Yoplantisi, 10, 1988, p. 305310.

Humphrey 1996 = J. Humphrey, "Amphitheatrical» hippo-stadia, in A. Raban, K. Holum (eds.), Caesarea Maritima. A Retrospective after Two Millennia, Leiden, 1996, p. 121-129.

Humphrey 1986 = J. Humphrey, Roman Circuses: Arenas for Chariot Racing, Berkeley, 1986.

Janin 1953 = R. Janin, La géographie ecclésiastique de l'empire byzantine. III Les églises et les monastères, Paris, 1953.

Kehrberg - Ostrasz = I. Kehrberg, A. Ostrasz, A history of occupational changes at the site of the hippodrome of Gerasa in Jordan: Studies in the History and Archaeology of Jordan, 6, 1997, p. 167-73.

Kempf 2004 = D. Kempf, Paul the Deacon's Liber de episcopis Mettensibus and the role of Metz in the Carolingian realm, in Journal of Medieval History, 20, 2004, p. 279299.

Krause - Witschel $2006=$ J.-U. Krause, C. Witschel (eds.), Die Stadt in der Spätantike - Niedergang oder Wandel? Stuttgart, 2006.

Laskaris $2000=\mathrm{N}$. Laskaris, Monuments funéraires paleochrétiens (et byzantins) de Grèce, Athens, 2000.

Lavan - Mulryan 2011 = L. Lavan, M. Mulryan (eds.), The Archaeology of Late Antique Paganism, Leiden, 2011.

Lavan 2001 = L. Lavan (ed.), Recent Research in LateAntique Urbanism, Portsmouth, 2001.

Lavan 2011 = The ends of the temples. Towards a new narrative?, in L. Lavan, M. Mulryan (eds.), The Archaeology of Late Antique Paganism, Leiden, 2011 , p. xv-lxv.

Leveau 1984 = P. Leveau, Caesarea de Maurétanie: une villa romaine et ses campagnes, Rome, 1984.

Leyerle 2001 = B. Leyerle, Theatrical Shows and Ascetic Lives: John Chrysostom's Attack on Spiritual Marriage, Berkeley, 2001.

Lim 1997 = R. Lim, Consensus and Dissensus on Public Spectacles in Early Byzantium, in Byzantinische Forschungen, 24, 1997, p. 159-179.

Lim 1999 = R. Lim, People as Power: Games, Munificence and Contested Topography, in W. V. Harris (ed.), The 
Transformation of VRBS ROMA in Late Antiquity, Portsmouth, 1999, p. 265-281.

Lim 2003 = R. Lim, Converting the un-Christianizable: The baptism of stage performers in late antiquity, in K. Mill, T. Grafton (eds.), Conversion in Late Antiquity and the Early Middle Ages, Rochester, NY, 2003, p. 84-126.

Mansel 1963 = A. M. Mansel, Die Ruinen von Side, Berlin, 1963.

Mansel 1964 = A. M. Mansel, Restaurationen und Umänderungen des Theaters von Side in byzantinsicher Zeit, Actes du XII Congrès international d'études byzantines, Ochride, 10-16 Septembre 1961, Belgrade, 1964, vol. 3, p. 239-244.

Mansel 1978 = A. M. Mansel, Side. 1947-1966 yillari kazilari ve araştirmalarinin sonuçlari, Ankara, 1978.

Mansi 8 = J. D. Mansi, Sacrorum Conciliorum Nova Amplissima Collectio, Tomus octavus ab anno ccccxii ad annum dxxxvi inclusive, Florence, 1762.

Markus $1979=$ R. A. Markus, Religion et politique: comment ont pris fins les combats de gladiateurs, in Annales, 34, 1979, p. 651-671.

Miraj 1986 = L. Miraj, Amfiteatri i Durrësit, in Iliria, 1986, p. 151-169.

Müller 1938 = E. Müller, The hippodrome, in C. Kraeling (ed.), Gerasa. City of the Decopolis, New Haven, CT, 1938.

Olovsdotter $2005=\mathrm{C}$. Olovsdotter, The Consular Image. An Iconological Study of the Consular Diptychs, Oxford, 2005.

Ostrasz 1989 = A. Ostrasz, The hippodrome of Gerasa: A report on excavations and research, 1982-1987, in Syria 66, 1989, p. 51-77.

Patrich 2002 = J. Patrich, The martyrs of Caesarea: The urban context, in Liber Annuus, 52, 2002, p. 321-346.

Paul the Deacon, Liber de epicopis Mettensibus = Paulus Diaconus, Liber de episcopis Mettensibus, in G. H. Pertz ed.,Scriptorum rerum Merovingicarumtomus II, Hanover, 1829 (Monumenta Germaniae Historica, SS 2).

Percival 1996 = J. Percival, Saints, ghosts and the afterlife of the Roman villa, in L'antiquité classique, 65, 1996, p. 161-173.

Perkins 1995 = J. Perkins, The Suffering Self: Pain and Narrative Representation in the Early Christian Era, London-New York, 1995.

Peschlow 2004 = U. Peschlow, The churches of Nicea/Iznik, in Iznik through the Ages, Istanbul, 2004, p. 201-217.

Pickard-Cambridge $1946=$ A. W. Pickard-Cambridge, The Theatre of Dionysus in Athens, Oxford, 1946.

Pinon 1979 = P. Pinon, Reutilisations anciennes et dégagements modernes des monuments antiques. Arles, Nìmes, Orange et Trèves, Tours, 1979.

Porath 1995 = Y. Porath, Herod's "amphitheater» at Caesarea: A multipurpose entertainment building, in J. Humphrey (ed.), The Roman and Byzantine Near East: Some Recent Archaeological Research, Ann Arbor, MI, 1995, p. 15-27.

Porath 1996 = The evolution of the urban plan of Caesarea's southwest zone, in A. Raban, K. Holum (eds.), Caesarea Maritima. A Retrospective after Two Millennia, Leiden, 1996, p. 105-120.

Porath 1998 = The Caesarea excavation project, in Hadashot Arkheologiyot. Excavations and Surveys in Israel, 17, 1998.
Ravoisié 1846 = Ravoisié, Exploration scientifique de l'Algerie, vol. 3, Paris, 1846.

Retzleff 2003 =A. Retzleff, Near Eastern Theatres in Late Antiquity, in Phoenix, 57, 2003, p. 115-138.

Rodriguez Oliva $1993=$ P. Rodríguez Oliva, Nuevas investigaciones sobre el teatro romano de Málaga, in Cuadernos de Arquitectura Romana 2, 1993.

Roueché $1991=C$. Roueché, Inscriptions and the later history of the theater, Aphrodisias Papers 2. The Theater, A Sculptor's Workshop, Philosophers and Coin-Types, Ann Arbor, MI, 1991.

Saradi $1990=$ H. Saradi, Christian attitudes toward pagan monuments in Late Antiquity and their legacy in later Byzantine centuries, in Dumbarton Oaks Papers, 44, 1990, p. 47-61.

Saradi $2006=$ The Byzantine City in the Sixth Century. Literary Images and Historical Reality, Athens, 2006, p. 355-64.

Sauer 2011 = E. W. Sauer, Religious rituals at springs in the late antique and early medieval world, in The Archaeology of Late Antique Paganism, L. Lavan, M. Mulryan (eds.), Leiden, 2011 , p. 505-550.

Shaw 1996 = B. Shaw, Body/Power/Identity: Passions of the Martyrs, in Journal of Early Christian Studies, 4, 1996, p. 269-312.

Smith 1987 = J. Z. Smith, To Take Place: Toward Theory in Ritual, Chicago, 1987.

Thür $1996=\mathrm{H}$. Thür, Die spätantike Bauphase der Kuretenstraße, in R. Pillinger et al. (eds.), Efeso Paleocristiana e Bizantina - Frühchristliches und Byzantinisches Ephesos, Rome, 1996, p. 104-120.

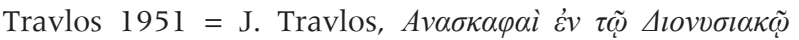

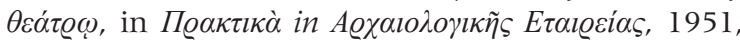
p. 41-45.

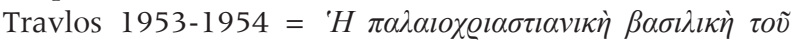

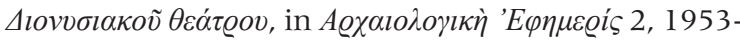
1954, p. 301-316.

Trombley 1993 = F. Trombley, Hellenic Religions and Christianization c. 370-529, Leiden, 1993, vol. 1, 108147.

Vaes 1989 = J. Vaes, "Nova construere sed amplius vetusta servare": La réutilisation chrétienne d'édifices antiques (en Italie), in Actes du XI'me Congrès International d'Archéologie Chrétienne. Lyon, Vienne, Grenoble, Genève et Aoste 1986, Rome, 1989, p. 299-321.

Ville $1960=\mathrm{G}$. Ville, Les jeux de gladiateurs dans l'empire Chrétien, in MEFRA, 72, 1960, 273-335.

Ward-Perkins 2003 = B. Ward-Perkins, Reconfiguring sacred space: from pagan shrines to Christian churches, in G. Brands, H.-G. Severin (eds.), Die spätantike Stadt und ihre Christianisierung, Weisbaden, 2003, p. 285-290.

Webb 2009 = R. Webb, Demons and Dancers. Performance in Late Antiquity, Cambridge, MA, 2009, 24-43.

Welch $1998=\mathrm{K}$. Welch, The stadium at Aphrodisias, in American Journal of Archaeology, 102, 1998, p. 547-569.

Wiegand - Schrader 1921 = T. Wiegand, H. Schrader, Priene: Ergebnisse der Ausgrabungen und Untersuchungen in den Jahren 1895-1898, Berlin, 1904, 478-479; 486. A. Gerkan, Das Theater von Priene, Munich-BerlinLeipzig, 1921. 